\title{
Explaining prehistoric variation in the abundance of large prey: A zooarchaeological analysis of deer and rabbit hunting along the Pecho Coast of Central California
}

\author{
Brian F. Codding ${ }^{a}$, Judith F. Porcasi ${ }^{b}$, Terry L. Jones ${ }^{c}$ \\ ${ }^{a}$ Department of Anthropology, Stanford University, 450 Serra Mall, Building 50, Stanford, CA 94305, USA \\ ${ }^{\mathrm{b}}$ Cotsen Institute of Archaeology, University of California, Los Angeles, CA 90095, USA \\ ${ }^{\mathrm{c}}$ Department of Social Sciences, California Polytechnic State University, 1 Grand Avenue, San Luis Obispo, CA 93407, USA
}

\begin{abstract}
A B S T R A C T
Three main hypotheses are commonly employed to explain diachronic variation in the relative abundance of remains of large terrestrial herbivores: (1) large prey populations decline as a function of anthropogenic overexploitation; (2) large prey tends to increase as a result of increasing social payoffs; and (3) proportions of large terrestrial prey are dependent on stochastic fluctuations in climate. This paper tests predictions derived from these three hypotheses through a zooarchaeological analysis of eleven temporal components from three sites on central California's Pecho Coast. Specifically, we examine the trade-offs between hunting rabbits (Sylvilagus spp.) and deer (Odocoileus hemionus) using models derived from human behavioral ecology. The results show that foragers exploited a robust population of deer throughout most of the Holocene, only doing otherwise during periods associated with climatic trends unfavorable to larger herbivores. The most recent component (Late Prehistoric/Contact era) shows modest evidence of localized resource depression and perhaps greater social benefits from hunting larger prey; we suggest that these final changes resulted from the introduction of bow and arrow technology. Overall, results suggest that along central California's Pecho Coast, density independent factors described as climatically-mediated prey choice best predict changes in the relative abundance of large terrestrial herbivores through the Holocene.
\end{abstract}

Keywords:

Foraging, Resource depression, Prestige hunting, Paleoclimatic variability, Human behavioral ecology, Zooarchaeology, Central California

\section{Introduction}

Factors that cause diachronic variation in the zooarchaeological abundance of large prey have been the center of much debate in recent decades. Researchers focused on hunter-gatherer populations have attempted to address this issue in many locations around the world, including South Africa (e.g., Binford, 1984; Klein, 1975, 1976, 1982; Klein et al., 2007), Western Europe (e.g., Binford, 1983; Grayson and Delpech, 1998, 2003; Grayson et al., 2001; Jochim, 1976, 1998), the Mediterranean Basin (e.g., Stiner, 2001, 2006; Stiner and Munro, 2002; Stiner et al., 2008; Stutz et al., 2009) and Western North America (e.g., Bayham, 1979; Broughton, 2002; Broughton and Bayham, 2003; Broughton et al., 2008; Butler, 2000; Butler and Campbell, 2004; Byers and Broughton, 2004; Byers and Ugan, 2005; Byers et al., 2005; Cannon, 2000, 2003; Codding and Jones, 2007a; Hildebrandt and McGuire, 2002; Hildebrandt et al., 2010; Hockett, 2005; Janetski, 1997; Jones and Codding, 2010; Jones et al., 2008a, 2009; McGuire and Hildebrandt, 2005; McGuire et al., 2007; Whitaker, 2009). From the research dealing with remains deposited by behaviorally modern humans, three main hypotheses have emerged that attempt to explain patterned fluctuations in the abundance of large prey.

The first hypothesis states that this patterning is caused by optimal economic decisions that lead foragers to preferentially target larger prey over smaller prey, which, over time results in the depression of large prey populations and a subsequent decline in their archaeological proportions (see Bayham, 1979; Broughton, 1994). Predictions derived from the resource depression hypothesis suggest that the prolonged acquisition of large prey negatively impacts their populations (although, see Whitaker, 2008, 2009), leading foragers to shift to smaller prey which is archaeologically identified by (P1a) a reduction in proportion of larger prey to smaller prey (e.g., Broughton, 1994; Stutz et al., 2009) and (P1b) changes in age structure of larger prey (e.g., Stiner, 2006), both of which may either influence, or be influenced by forager settlement and mobility, (P1c) resulting in changes in the processing and transport of skeletal elements from large prey (Cannon, 2000, 2003).

The second hypothesis proposes that patterns in the proportion of large prey remains are driven by changes in the size of social 
groups and/or the frequency of social aggregations both of which are linked to the social payoffs of hunting (Hildebrandt and McGuire, 2002, 2003; Hildebrandt et al., 2010; McGuire and Hildebrandt, 2005; McGuire et al., 2007, see also Aldenderfer, 2006; Cannon, 2009; Potter, 1997, 2000; Plourde, 2008). Predictions from the prestige hunting hypothesis suggest that an increase in the social payoffs of large game hunting should lead to (P2a) a diachronic increase in the archaeological visibility of large prey relative to small prey, accompanied $(P 2 b)$ by an increase in the logistic mobility of foragers (sensu Binford, 1980) caused by hunters having to travel further to acquire large prey at higher costs.

The third hypothesis suggests that proportional fluctuations in large prey remains reflect stochastic climatic variability that differentially impacts large terrestrial herbivores over smaller prey. Predictions from the environmental stochasticity hypothesis suggest that (P3) climatic changes associated with either mean aridity or extreme seasonality negatively impact large herbivore populations (i.e., artiodactyls) more severely than smaller prey (i.e., leporids), causing a decrease in the encounter rates with large prey and a decrease in their archaeological visibility (Byers and Broughton, 2004; Broughton and Bayham, 2003; Broughton et al., 2008; Grayson and Delpech, 1998).

The outcome of these debates has the potential to influence our understanding of a suite of issues, including the ecological impacts of forager subsistence strategies, the social and ritual role of large game hunting, and the effect of environmental variability on human behavior. However, to work thorough these hypotheses, zooarchaeological analysis must disentangle the multiple causes that may lead to the same material pattern (Klein and Cruz-Uribe, 1984; see also Grayson, 1984; Lyman, 1993, 2008; Reitz and Wing, 2008). Here we attempt to accomplish this by testing the above predictions with a zooarchaeological analysis of 11 well-dated components from three sites on the Pecho Coast of Central California (Fig. 1); these sites represent all of the excavated assemblages in the study area that have produced significant numbers of faunal remains, and our geographic limit focuses our controlled comparisons (sensu Klein and Cruz-Uribe, 1984) on temporal rather than spatial variability. Importantly, it must first be shown that temporal variation in the abundance of large prey within these assemblages results neither from variation in sample size (see Grayson, 1978, 1981, 1984; see also Cannon, 2001) nor taphonomic processes (e.g., Lyman, 1984, 1985, 1994). Then, analysis may turn to quantitative tests of foraging models derived from human behavioral ecology (for an overview, see Smith and Winterhalder, 1992; Winterhalder and Smith, 2000; for an archaeologically specific review, see Bettinger, 1991: pp. 83-130, 2006; Bird and O'Connell, 2006; Grayson and Cannon, 1999; Lupo, 2007). By deriving predictions from general models applicable to zooarchaeological data, researchers have been able to successfully unravel the possible sources of variation in archaeofaunal assemblages. In this paper we test quantitative predictions derived from each alternative hypothesis, focusing on the trade-offs between hunting larger, mobile terrestrial prey (deer) and smaller less mobile terrestrial prey (rabbits). ${ }^{1}$ While not the final word on the subject, a careful examination of these data will help to shed light on the debates surrounding the causes of variation in large prey abundance and con-

\footnotetext{
1 The term "mobility" is here used as Bird et al. (2009), to refer to a prey's ability to evade capture during post-encounter pursuit. While rabbits may indeed be fast over short distances, we suggest that at the scale which matters in this context, deer are better able to evade a hunter by moving outside the range of hand-held or even projectile weapons. This suggests that while deer may be larger than rabbits and thus provide a larger harvest, pursuit success may be more variable as a function of their mobility (see also Jochim, 1976; Stiner et al., 2000). For this reason, it should not be assumed a priori that deer are a higher ranked resource than rabbits. However, quantitative experimental work in western North America is needed to confirm this particularly useful would be data on pursuit successes and failures with deer and rabbits using various technologies.
}

tribute to our overall understanding of prehistoric human-prey dynamics.

\section{Archaeological and environmental background}

After Greenwood's (1972) initial work in the region, Jones $(1993,2003)$ was the first to systematically integrate material culture sequences along the central California coast with the well established cultural chronologies of the San Francisco Bay and Sacramento/San Joaquin Delta area in the north (e.g., Bennyhoff, 1978; Bennyhoff and Hughes, 1987; Lillard et al., 1939) and the Santa Barbara Channel to the south (e.g., King, 1982, 1990; Rogers, 1929). Most recently, the central coast sequence has been defined by six distinct periods (Jones et al., 2007):

\author{
I. Late (700-181 $\left.\mathrm{BP}^{*}\right)$ \\ II. Middle-Late Transition (MLT; 950-700 BP*) \\ III. Middle (2550-950 BP $)$ \\ IV. Early (5450-2550 $\left.\mathrm{BP}^{*}\right)$ \\ V. Millingstone (or Early Archaic; $9950-5450 \mathrm{BP}^{*}$ ) \\ VI. Paleo-Indian (pre-9950 BP $^{*}$ )
}

While the Paleo-Indian Period is marked only by isolated fluted projectile points (e.g., Mills et al., 2005), large residential middens dating to all of the later periods are common throughout the region in varying densities (Jones et al., 2007). The earliest middens dating to the Millingstone Period frequently occur on the coast or show some connection with the coast (i.e., the presence of shellfish). While some sites show an emphasis on marine resources, others suggest an emphasis on terrestrial prey; when all the Millingstone assemblages in the region are examined together, subsistence appears diverse including shellfish, birds, mammals, fish, seeds and other plant resources (Jones et al., 2007, 2002, 2008a, 2009). Milling equipment including slabs and hand stones are ubiquitous and projectile points occur less frequently than during later time periods.

The transition to the Early Period is marked by an increase in the number of sites occupied suggesting an increase in population density; technological changes include the initial adoption of the mortar and pestle and an increase in the quantity of multifunctional projectile points, most of which belong to the central coast stemmed series (Jones et al., 2007; Stevens and Codding, 2009). An increase in exogenous obsidian also suggests a spike in interregional trade (Jones et al., 2007; see also Jones, 2003). These trends continue through the Middle Period, captured by Jones et al.'s (2007) reference to both time periods as a material expression of the same "Hunting Culture" (sensu Rogers, 1929; see also Greenwood, 1972).

The continuity of the Early and Middle periods is disrupted by an abrupt transition phase referred to as the Middle-Late Transition Period. This time period is marked by widespread site abandonment (Jones and Ferneau, 2002; Jones et al., 2007, 1999) and rapid changes in technology including the adoption of smaller, more specialized projectile points (Stevens and Codding, 2009) and fishhooks (Codding and Jones, 2007a; Codding et al., 2009). In many ways this period is a true transition, characterized by a combination of traits that when recovered independently, differentiate the Early/Middle and Late Periods.

The Late Period is marked by a proliferation of single component sites associated with bedrock mortars; these sites occur more frequently in the interior, albeit with continued, but proportionally reduced occupation of the coast (Jones et al., 2007). Both inland and coastal sites show evidence of being occupied year round (Jones et al., 2008b). The Late Period is also typified by the adoption of small uniform projectile points associated with bow and arrow technology (Jones et al., 2007). 


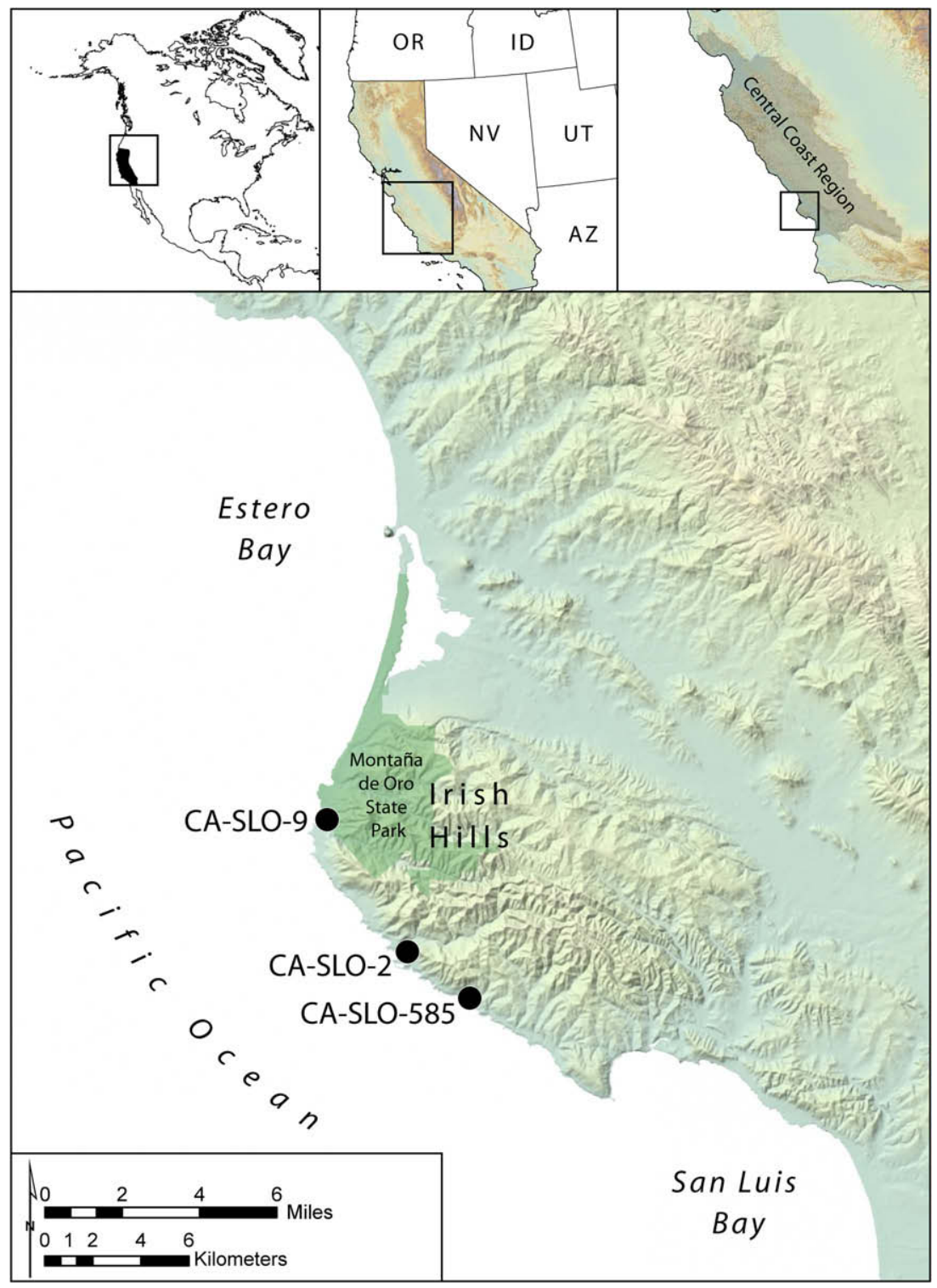

Fig. 1. Site locations situated along the Pecho Coast within the Central Coast Region of California.

The Pecho Coast

Situated within the Central Coast Region (sensu Moratto, 1984; see also Jones et al., 2007), the Pecho Coast is a $20 \mathrm{~km}$ wide peninsula extending about $8 \mathrm{~km}$ into the Pacific Ocean between Morro (Estero) Bay and San Luis Obispo Bay in San Luis Obispo County, California (Fig. 1). Just east of the coastal terrace, low mountains known as the Irish Hills rise sharply to elevations of about $550 \mathrm{ft}$. With this increase in elevation, the landscape transitions from mosaics of coast scrub and chaparral to coastal oaks, chaparral and grasslands bisected by a series of small, densely wooded drainages that flow to the Pacific Ocean. The mouths of these creeks form small sandy beaches along a coastline otherwise dominated by exposed rocky shores, cliffs and bluffs.

To date, nearly 50 shell middens are known along the Pecho Coast. The first systematic work was performed by Pilling (1951), who surveyed the area and described some of the surface findings. Since that time, various test excavations have provided information on temporary camps (e.g., Breschini and Haversat, 1988), how- ever, only three residential sites have been excavated extensively enough to produce significant faunal assemblages: CA-SLO-2, CASLO-9, and CA-SLO-585 (see Codding and Jones, 2006, 2007a; Codding et al., 2009; Greenwood, 1972; Jones et al., 2008a, 2009). Greenwood (1972) excavated six sites in preparation for the construction of Diablo Canyon Nuclear Power Plant in 1968. Two of these sites (CA-SLO-2, -585) provided substantial trans-Holocene faunal assemblages that were not analyzed until recently (Jones et al., 2008a, 2009). Each of the Diablo sites has produced diverse artifact assemblages indicating that they functioned as residential bases, with no substantive evidence for changes in site function through time (Jones et al., 2008a, 2009). The Coon Creek site (CASLO-9) was excavated between 2004 and 2007 in order to salvage a portion of the midden that was eroding into the Pacific Ocean (Codding and Jones, 2007a; Codding et al., 2009). While findings from these sites have been discussed individually (Codding and Jones, 2007a; Codding et al., 2009; Greenwood, 1972; Jones et al., 2008a, 2009), results from all of this work are synthesized here for the first time. 


\section{Methods and models}

\section{Excavation methods}

CA-SLO-2 and CA-SLO-585 were excavated in 1968 with a mixed recovery strategy aimed at generating substantial samples of diagnostic artifacts, macro and micro faunal constituents. All units were excavated in $10 \mathrm{~cm}$ arbitrary levels (see Greenwood, 1972; Jones et al., 2008a, 2009). After excavation, all material was curated at the San Luis Obispo County Archaeological Society Collection Facility in 1972 from which it was retrieved for analysis in 2004.

Excavations at CA-SLO-2 resulted in a total recovery volume of $109 \mathrm{~m}^{3}$ from a deposit that extended to a depth of $3.4 \mathrm{~m}$. (Greenwood, 1972). After 32 years of storage, some of the collections (or their provenience) were lost or damaged, but remains from $98.9 \mathrm{~m}^{3}$ were still available for analysis in 2004. Most of the recovery volume came from $301 \times 2 \mathrm{~m}$ units that were excavated by hand in arbitrary $10-\mathrm{cm}$ levels processed with $6-\mathrm{mm}(1 / 4 \mathrm{in}$.) mesh dry screens. In addition, a $0.25 \times 0.25 \mathrm{~m}$ column sample was excavated $\left(0.8 \mathrm{~m}^{3}\right)$ and wet screened with $1-\mathrm{mm}$ mesh; and a $1 \times 1 \mathrm{~m}$ unit, was screened with nested $6-\mathrm{mm}(1 / 4 \mathrm{in}$.) and 3-mm (1/8 in.) mesh (see also Jones et al., 2008a).

At CA-SLO-585, a total of $39.4 \mathrm{~m}^{3}$ was excavated by hand from ten $1 \times 2 \mathrm{~m}$ units screened dry with $6-\mathrm{mm}(1 / 4 \mathrm{in}$.) mesh, and one $1 \times 1 \mathrm{~m}$ control column was used to sample shell and small fish remains. In addition to these hand excavated units, $30.0 \mathrm{~m}^{3}$ of deposit was excavated mechanically with a backhoe for a total recovery volume of $69.4 \mathrm{~m}^{3}$ (see Greenwood, 1972; Jones et al., 2009).

CA-SLO-9 was excavated between 2004 and 2007 through a joint partnership between the California State Parks Department (Department of Parks and Recreation, DPR) and California Polytechnic State University, San Luis Obispo (see Codding and Jones, 2006, 2007a; Codding et al., 2009). Nineteen $1 \times 2 \mathrm{~m}$ units were excavated and processed with $3-\mathrm{mm}(1 / 8 \mathrm{in}$.) mesh and one $1 \times 2 \mathrm{~m}$ unit was processed with $6-\mathrm{mm}(1 / 4 \mathrm{in}$.) mesh. In addition, three $1 \times 1 \mathrm{~m}$ control units were water-processed through $3-\mathrm{mm}$ (1/8 in.) mesh and sorted in the laboratory.

\section{Radiometric determinations and component definitions}

A total of 51 radiocarbon dates was used to define components for the current study (CA-SLO-2 $=34$; CA-SLO-9 $=7$; CA-SLO$585=10$; see Codding and Jones, 2007a; Jones et al., 2008a, 2009). Dates were calibrated using CALIB 5.0.2 (Stuiver et al., 2005 ) with a local marine correction curve of $290 \pm 35$ for dates obtained from shell (Stuiver and Reimer, 1993). All dates reported here are calibrated, as denoted by an asterisk. A chronology was developed based on the relationship between depth and the mid- points of the calibrated radiocarbon dates. Components were then contextually situated based on the regional chronology of Jones et al. (2007). While this technique cannot increase the chronological precision of the components, which is often reduced in these open-air middens as a result of post-depositional mixing, it does accurately categorize components in a less biased way than simply lumping faunal remains by cultural time period. Moreover, this approach attempts to define the unit of analysis (the component) at the smallest scale allowed by the chronological controls in order to avoid problems associated with artifactual patterns that may result from temporal averaging (Lyman, 2003; Jones and Codding, 2010).

For the two multi-component sites (CA-SLO-2 and CA-SLO-585), calibrated midpoint (years BP) values were plotted against minimum depth and the relationship was fitted with a smoothing spline ( $\lambda=10,000$; see Fig. 2 ). Two extreme outliers were excluded from the CA-SLO-2 dates. The spline essentially describes the relationship between depth and date by interpolating unknown values and without making any strong assumptions about rates of deposition. The spline and associated radiocarbon dates were used to determine the vertical extent of each occupational deposit in 1000 and 2000 year increments for CA-SLO-2 and CA-SLO-585 respectively. One exception was the $500 \mathrm{BP}^{*}$ component at CASLO-585, which overlaps with the same component at CA-SLO-2. Because of this, these two components were aggregated to represent about the last 1000 years of occupation (the Late Period). The defined components relative to time and depth are shown in Fig. 2. Table 1 provides a summary of each temporal component by depth. Each faunal element was assigned to a corresponding 1000 or 2000 year period based on depth. For all subsequent analyses, each time period was plotted at the midpoint value (e.g., $1000-2000 \mathrm{BP}^{*}$ is plotted at $1500 \mathrm{BP}^{*}$ ). The midpoint for each component differs, thus each component is referenced by its associated calibrated midpoint in years $\mathrm{BP}^{*}$.

As the assemblage from CA-SLO-9 represents a single component dating to the Middle-Late Transition Period (see Codding and Jones, 2006, 2007a; Codding et al., 2009), and because this time period was lacking from both of the Diablo Canyon sites (see Jones et al., 2008a, 2009), data from CA-SLO-9 were plotted at the $1000 \mathrm{BP}^{*}$ point as it represents the transition between the final Middle period component centered at $1500 \mathrm{BP}^{*}$ and the Late Period component centered at $500 \mathrm{BP}^{*}$.

\section{Zooarchaeological methods, measures and models}

All bird, mammal, and reptile remains were identified by Judith Porcasi using reference collections from the Los Angeles County Museum of Natural History and the Zooarchaeology Laboratory

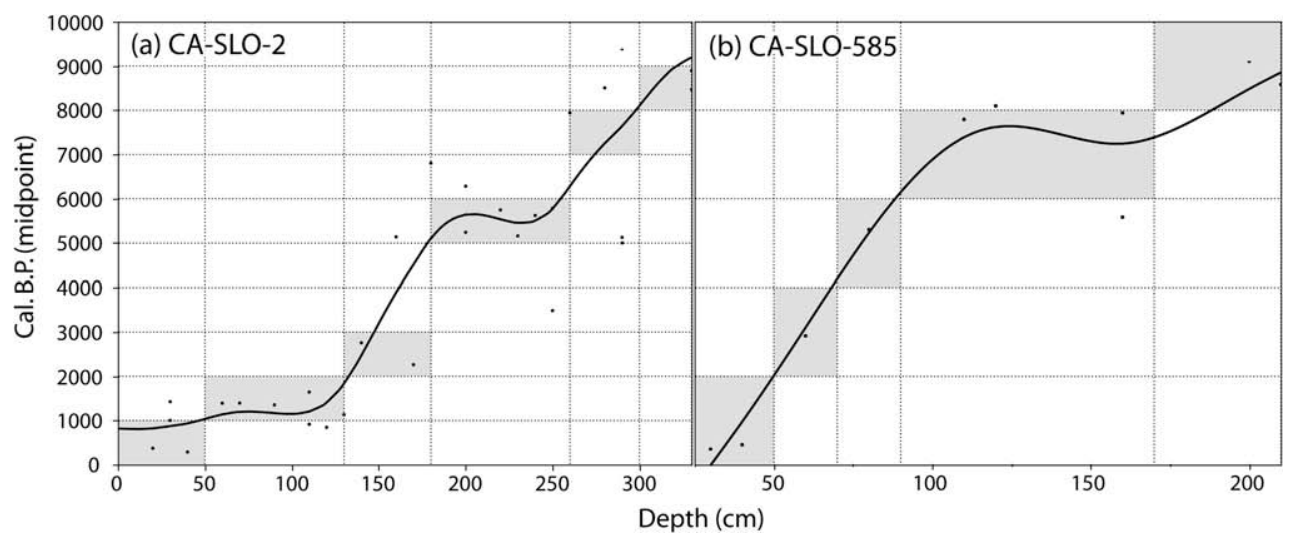

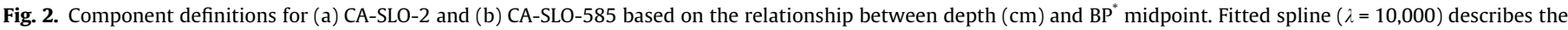
relationship between depth and calibrated years BP. Components appear in shaded grey. 
Table 1

Component definitions.

\begin{tabular}{|c|c|c|c|c|c|c|}
\hline No. & Site & Depth $(\mathrm{cm})$ & $\mathrm{BP}^{*}$ midpoint $^{\mathrm{a}}$ & $\mathrm{BP}^{*}$ range & Cultural period $^{\mathrm{b}}$ & Geologic period $^{\mathrm{c}}$ \\
\hline 1 & CA-SLO-2 & $0-50$ & 500 & $0-1000$ & Late & Late Holocene \\
\hline 1 & CA-SLO-585 & $0-50$ & 500 & $0-1000$ & Late & Late Holocene \\
\hline 2 & CA-SLO-9 & $0-110$ & 1000 & $700-1000$ & MLT & Late Holocene \\
\hline 3 & CA-SLO-2 & $50-130$ & 1500 & $1000-2000$ & Middle & Late Holocene \\
\hline 4 & CA-SLO-2 & $130-180$ & 2500 & $2000-3000$ & Middle & Late Holocene \\
\hline 5 & CA-SLO-585 & $50-70$ & 3000 & $2000-4000$ & Middle & Late Holocene \\
\hline 6 & CA-SLO-585 & $70-90$ & 5000 & $4000-6000$ & Early & Middle Holocene \\
\hline 7 & CA-SLO-2 & $180-260$ & 5500 & $5000-6000$ & Early & Middle Holocene \\
\hline 8 & CA-SLO-585 & $90-170$ & 7000 & $6000-8000$ & Millingstone & Middle Holocene \\
\hline 9 & CA-SLO-2 & $260-300$ & 7500 & $7000-8000$ & Millingstone & Middle Holocene \\
\hline 10 & CA-SLO-2 & $300-330$ & 8500 & $8000-9000$ & Millingstone & Early Holocene \\
\hline 11 & CA-SLO-585 & $170-220$ & 9000 & $8000-10,000$ & Millingstone & Early Holocene \\
\hline
\end{tabular}

a All dates refer to calibrated years before present.

b Assigned following the cultural chronology by Jones et al. (2007).

c Assigned by dividing the Holocene (12,000 years) into three even periods.

at the Cotsen Institute of Archaeology at University of California, Los Angeles. All specimens were identified to the most discrete taxonomic level possible based on diagnostic features. In the absence of such features, bones were assigned to classes (e.g., Mammal, Aves, etc.) or subclasses (e.g., marine mammal, carnivore, etc.) and to size categories (small, medium, or large). In addition, the element, part of element, side, age, number, weight, and evidence of modification (i.e., burned, gnawed, cut, or worked) were, to the degree possible, recorded for each specimen. The age of specimens was determined by reference to the degree of epiphyseal fusion: detached epiphyses and diaphyses lacking epiphyses were classified as juvenile, diaphyses with partially fused epiphyses were considered sub-adult and fully fused epiphyses were classified as adult. Data were entered into Microsoft Access ${ }^{\mathrm{TM}}$. Tabular data from each site were then compiled in a database where each layer for each site was linked with an associated temporal position determined by radiocarbon dates (see above).

Before the datasets were evaluated relative to the three alternative hypotheses, assemblages were evaluated to determine if patterning could be the result of sample size or density mediated attrition. The effect of sample size on zooarchaeological prey abundance was examined by comparison with the total NISP for each component. The effect of density mediated attrition was examined following Grayson (1988). Bulk density values from Lyman (1984, 1985) were assigned to each non-repeatable artiodactyl element for each component unit level. Counts were based on the best represented section elements (e.g., distal ends of phalanges, acetabulum of the innominate, the glenoid fossa of scapulas, etc.). Limb shafts were excluded and only the vertebral body (or centrum) and the articular ends of ribs were counted. Only the earliest component $\left(9000 \mathrm{BP}^{*}\right)$ from CA-SLO-585 was excluded from the analysis because it lacked any elements to which bulk density values could be assigned due to small sample size.

The second and main set of analyses involved deriving and testing predictions from each hypothesis within a framework of behavioral ecology. Two models were utilized: the prey choice model (PCM; see MacArthur and Pianka, 1966; Schoener, 1971; Stevens and Krebs, 1986), and a central place foraging model (CPF; see Metcalfe and Barlow, 1992; Orians and Pearson, 1979; see also Bettinger et al., 1997). Archaeological applications of each are reviewed and discussed by Bettinger (1991: pp. 83-130), Bird and O'Connell (2006), Grayson and Cannon (1999), Lupo (2007) and Shennan (2008).

\section{Zooarchaeological measures of prey choice}

In order to test predictions derived from the PCM, prey abundance and diversity indices were calculated for each temporal component. Following the logic outlined by Bayham (1979; see also Broughton, 1994), abundance indices were calculated for each component as the proportion of the number of specimens identifiable (NISP) to the larger taxa relative to the number of specimens identifiable to the smaller taxa, or:

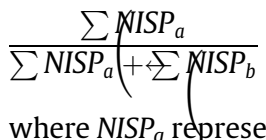

presents the total number of bones identifiable to the larger taxa and $N_{I S P}$ represents the total number of bones identifiable to the smaller taxa at some consistent taxonomic level. So to remain comparable with the variety of ways in which abundance indices have been calculated in previous work, and to make sure that diachronic trends are consistent across levels of taxonomic identification, this study calculates three indices: (1) the Odocoileus Index (OI) measures the ratio of all Odocoileus hemionus remains relative to all 0 . hemionus plus Sylvilagus spp. remains; (2) the Artiodactyl Index (AI) measures the same trade-off but at higher taxonomic level, examining the ratio of all Artiodactyl remains relative to all artiodactyl plus Leporid remains; (3) the proportion of $O$. hemionus remains to the total NISP of economically significant terrestrial taxa identified to the genus level (\% Odocoileus), which measures the trade-off between hunting deer or engaging in any other terrestrial hunting activity. These indices are designed to measure the trade-offs associated with searching (in a patch) and pursuing one prey type over another or the trade-offs between deciding to hunt one prey type over the other if they occur in two separate patches. The latter models prey choice analogous to Smith's (1991) usage.

Originally, abundance index values were presumed to measure the encounter rates with the higher-ranked prey type assuming that prey rank scales with prey body size (see Griffiths, 1975; Simms, 1985; Ugan, 2005; Wilson, 1976; but see Stiner et al., 2000). Based on this logic, abundance indices should provide a proxy measure for overall return rate (see Bayham, 1979). However, recent research has shown that body size is not a reliable measure of post-encounter return rate due to the positive correlations between prey body size, prey mobility, and pursuit failures (Bird et al., 2009; see also Lee, 1968; Sih and Christensen, 2001; Smith, 1991; Winterhalder, 1981). If prey encounters are rare, a single failed pursuit may indeed lead to a failed overall foraging bout (and thus a return rate of 0 ); however, dense patches of larger prey may mitigate this risk as a forager's overall probability of bout success (that is, returning with something) increases with each encounter and pursuit. In this sense, the probability of bout success with larger prey may be a more significant predictor of prey choice than simply post-encounter return rate. However, unlike a prey item's post-encounter return rate, bout success is expected to 
change across time and space, potentially with predictable results (see Bird et al., 2009; Bliege Bird et al., 2009). In order to deal with such issues of prey rank, zooarchaeological analyses should utilize multiple measures when evaluating predictions derived from the PCM, one of the most useful being assemblage diversity (Lupo, 2007: 157-158; see also Dean, 2007).

Margalef's Index and Simpson's Index were calculated from the economically significant terrestrial fauna (Table 1 ), which excludes potentially invasive burrowing rodents; each index corresponds to the two commonly measured components of diversity: richness $(S)$ and evenness $(D)$ respectively (see Magurran, 1988, 2004). Margalef's index is essentially the number of taxa in an assemblage ( $S$ or ¿TAXA, see Grayson, 1984; Lupo, 2007) with control for sample size effects. Evenness measures the degree to which the species in an assemblage are equally represented; its opposite, sometimes referred to as dominance, is interpreted as the degree to which an assemblage is dominated by a single species. Simpson's index is ideal for relatively small samples as it makes no assumption about the underling distribution of the population from which the sample was drawn, moreover it has an intuitive interpretation: the probability that two individuals randomly drawn from the sample will belong to different species (see Magurran, 2004). Simpson's index was calculated with the following equation:

$\left.D=E\left(\frac{\eta_{i}\left[n_{i}-1\right]}{N[N-1]}\right)\right)($

where $n_{i}$ equals the number of individuals in the $i$ th species and $N$ equals the total number of individuals (Magurran, 2004). In order to have the index value increase with evenness, it is typically represented as $1 / D$. Magurran (2004:239) provides a worked out example.

The basic prediction derived from the PCM states that if foragers experience declines in encounter rates (or perhaps bout success rates) with higher-ranked prey, then foragers should widen their "diet breadth" (the evenness component of diversity) by incorporating lower-ranked items into the diet. This also holds true if we consider the key variable to be variability in hunting bout success. This prediction avoids the troubles with ranking prey as a more diverse diet should correspond with decreasing encounter (or bout success) rates with higher-ranked prey (whatever that prey may be) (see e.g., Dean, 2007). While this approach seems to work (Jones, 2004), because diversity measures lack any measure of rank, they alone are problematic since prey ranking is central to the PCM (Winterhalder and Bettinger, 2010; see also Madsen, 1993; but see Broughton and Grayson, 1993). However, if evenness indices are highly correlated with changes in the relative abundance of larger prey, then the changes in large prey may be symptomatic of overall trends affecting human subsistence patterns, including but not limited to, lower overall encounter rates with highly ranked prey. In essence, diachronic correlations between abundance index values and the evenness component of diversity can be thought of as a diagnostic test to determine whether or not the prey in question (the sole numerator of the abundance index) is highly ranked.

\section{Zooarchaeological measures of central place foraging}

While considerations of prehistoric prey choice outline the search and handling components of foraging, understanding prehistoric foraging decisions often requires an understanding of the processing and transport components of resource acquisition. To this end, research here utilized a CPF model. Building on Orians and Pearson (1979), Metcalfe and Barlow (1992; alternatively see Bettinger et al., 1997) developed a formal model examining the trade-offs human foragers face when attempting to transport re- sources from an acquisition location back to a home base. The basic model assumes that a given forager's goal is to maximize the rate at which resources are delivered to a central place. Depending on the distance (travel time), the number of foragers and the size and character of the resource, foragers must decide whether to return home with an unprocessed resource (bulk transport) or differentially process resources in the field prior to transport (field processing and partial discard). As different parts of the same plant or animal resource vary in their potential food utility (e.g., bone vs. meat), the model predicts that if foragers are trying to maximize the utility of a single load returned home, they should differentially process low utility parts (leaving them at the acquisition site) and transport high utility parts home. When the distance from the acquisition point is large, the model predicts that foragers will differentially process and discard elements to a higher extent than when distances are short. When distances are very short, the model predicts that foragers will field process to the lowest extent possible and make multiple trips to the central place. Cannon (2003) incorporated elements of a central place foraging model into a prey choice model to develop his central place forager prey choice model. Relying on two archaeologically visible variables (bone counts and utility value of bone elements), the model provides a tool for examining both the encounter rates with high ranked prey through abundance indices and the time foragers were required to travel in order to return the acquired prey to a central place.

The utility of a given element is calculated through Metcalfe and Jones's (1988) Standardized Whole Bone Food Utility Index or (S)FUI (see also Binford, 1978). Through an examination of (S)FUI values, differential field processing should be reflected at the central place by an overall increase in mean (S)FUI, representing the differential deposition of high utility parts. Trends in the opposite pattern (i.e., a decrease in (S)FUI values) are also indicative of differential butchering, possibly resulting from the removal of high value meat from high value bone in the field (see Lupo, 2001, 2006; O'Connell et al., 1988). To test this prediction, (S)FUI values were assigned to each non-repeating artiodactyl element or element complex per unit level following Cannon (2003). As with bulk density values, values were assigned only to the best represented section of a given element. One component (9000 $\left.\mathrm{BP}^{*}\right)$ lacked any artiodactyl specimens to which (S)FUI values could be assigned, and two others (5000 $\mathrm{BP}^{*}$ and $8500 \mathrm{BP}^{*}$ ) had only two each, all of these were excluded from further analysis. While (S)FUI values require additional refinement (see Lupo, 2006), comparing mean (S)FUI values between multiple components through time or space can be a useful relative measure of how butchering and transport decisions vary. Since, variation in (S)FUI values may ultimately be the product of density mediated attrition (Grayson, 1984, 1989; Lyman, 1984, 1985), the effect of bone density on patterns in (S)FUI values needs to be controlled (see above).

\section{Statistical methods}

As ordinary least squares (OLS) regression requires that the dependent variable is an unbound, normally distributed continuous variable, it is often an inappropriate model to use with archaeological data. The typical alternatives adopted in many zooarchaeological studies are rank order tests (e.g., Spearman's rho $[\rho])$. However, these tests unrealistically rank cases, losing continuous data in the process. To avoid the limitation of rank order tests, we utilized generalized linear models (GLM) with a specified distribution family (or error structure) and link function. When the dependent variable is bound between an upper and lower limit (e.g., between 0 and 1 ), as is the case for all proportional data and for most faunal indices of abundance and diversity, a binomial family GLM was used with a logit (or logistic) link function (see Crawley, 2007:513-526; 569-609; Faraway, 2006; Kieschnick 
Table 2

Summary of economically significant terrestrial fauna per component (BP* midpoint).

\begin{tabular}{|c|c|c|c|c|c|c|c|c|c|c|c|c|c|c|}
\hline Class & Family & Taxon & Common name & 500 & 1000 & 1500 & 2500 & 3000 & 5000 & 5500 & 7000 & 7500 & 8500 & 9000 \\
\hline Reptilia & Bufonidae & Bufo boreas & Western toad & 0 & 0 & 1 & 0 & 0 & 0 & 0 & 0 & 0 & 0 & 0 \\
\hline Amphibia & Testudinidae & Clemmys marmorata & Western pond turtle & 2 & 0 & 13 & 0 & 0 & 0 & 0 & 0 & 1 & 0 & 0 \\
\hline \multirow[t]{5}{*}{ Aves } & Accipitrinae & Aquila chrysaetos & Golden eagle & 0 & 0 & 1 & 0 & 0 & 0 & 0 & 0 & 0 & 0 & 0 \\
\hline & Corvidae & Corvus brachyrhynchos & Crow & 0 & 0 & 2 & 1 & 0 & 0 & 0 & 0 & 0 & 0 & 0 \\
\hline & Mimidae & Mimus polyglottos & Mocking bird & 0 & 1 & 0 & 0 & 0 & 0 & 0 & 0 & 0 & 0 & 0 \\
\hline & Phasianidae & Callipepla californica & California quail & 0 & 0 & 2 & 0 & 0 & 0 & 0 & 0 & 0 & 0 & 0 \\
\hline & Tytonidae & Tyto alba & Barn owl & 0 & 0 & 1 & 0 & 0 & 0 & 0 & 0 & 0 & 0 & 0 \\
\hline \multirow[t]{15}{*}{ Mammalia } & Leporidae & Lepus californicus & Jackrabbit & 0 & 1 & 2 & 0 & 0 & 0 & 1 & 0 & 0 & 0 & 1 \\
\hline & & Sylvilagus spp. & Cottontail rabbit & 38 & 52 & 185 & 52 & 2 & 1 & 64 & 7 & 23 & 3 & 13 \\
\hline & Castoridae & Castor canadensis & American beaver & 0 & 0 & 0 & 0 & 0 & 0 & 0 & 0 & 1 & 0 & 0 \\
\hline & Canidae & Canis sp. & Dog/Coyote & 14 & 13 & 73 & 11 & 3 & 0 & 7 & 0 & 4 & 1 & 2 \\
\hline & & Urocyon cinereoargenteus & Grey fox & 1 & 0 & 0 & 0 & 0 & 0 & 0 & 0 & 0 & 0 & 0 \\
\hline & & Vulpes vulpes & Red fox & 0 & 0 & 0 & 0 & 0 & 0 & 1 & 0 & 0 & 0 & 0 \\
\hline & Felidae & Felis concolor & Puma & 0 & 0 & 1 & 1 & 0 & 0 & 0 & 0 & 0 & 0 & 0 \\
\hline & & Lynx rufus & Bobcat & 1 & 1 & 6 & 1 & 0 & 0 & 3 & 0 & 0 & 0 & 1 \\
\hline & Mustelidae & Mephitis mephitis & Striped skunk & 2 & 1 & 1 & 0 & 0 & 0 & 0 & 0 & 0 & 0 & 0 \\
\hline & & Taxidea taxus & American badger & 2 & 0 & 4 & 0 & 1 & 0 & 0 & 0 & 0 & 0 & 0 \\
\hline & & Mustela sp. & Weasel & 0 & 0 & 1 & 1 & 0 & 0 & 0 & 0 & 0 & 0 & 0 \\
\hline & Procyonidae & Procyon lotor & Racoon & 4 & 3 & 5 & 2 & 0 & 0 & 1 & 0 & 0 & 0 & 0 \\
\hline & Cervidae & Cervus elaphus & Elk & 0 & 0 & 2 & 0 & 0 & 0 & 0 & 0 & 1 & 0 & 0 \\
\hline & & Odocoileus hemionus & Black-tailed Deer & 213 & 7 & 522 & 209 & 9 & 9 & 198 & 18 & 49 & 4 & 4 \\
\hline & & & Total & 277 & 79 & 822 & 278 & 15 & 10 & 275 & 25 & 79 & 8 & 21 \\
\hline
\end{tabular}

and McCullough, 2003). Following Menard (2002), likelihood ratios $\left(R_{L}^{2}\right)$ were calculated for each binomial-logit GLM as the -2 log-likelihood (-2LL) value of the difference $\left(G_{M}\right.$, or $\left.\chi^{2}\right)$ between the -2LL value of null model ( $D_{0}$, which includes only the intercept) and the -2LL value of the full model $\left(D_{M}\right.$, which includes the intercept plus the independent variable or variables) divided by the -2LL value of the null model $\left(D_{0}\right)$; in other words, $R_{L}^{2}=G_{M} / D_{0}$. In this form, $R_{L}^{2}$ values are equal to the reduction in unexplained deviance resulting from the inclusion of the independent variable(s) and can be interpreted as analogous to $r^{2}$ values in OLS regression. For each GLM the appropriate weights (or observations) were assigned for each component as the total number of possible faunal elements (e.g., for OI values, the total NISP of terrestrial fauna identified at the genus level).

Chi-square $\left(\chi^{2}\right)$ tests were also utilized to assess the differences in bone counts across assemblages. A Monte Carlo simulation (with 2000 iterations) was used to generate possible cell counts under the conditions imposed by the structure of the actual data (i.e., the number of cells plus row and column totals), from which a $\chi^{2}$ value is calculated and an alpha $(p)$ value assigned based on comparing the observed values to the iterated simulation (Hope, 1968; R Development Core Team, 2009). Secondary contingency table analysis examined the contribution of each individual cell count to the overall difference in the contingency table. To determine the contribution of each cell count to the significance of the $\chi^{2}$ test, the probability that each cell count could occur was calculated based on expected values generated from row and column totals. Drawing on the binomial probability theorem, this approach calculates the probability $(P)$ of some observed count, or "success" $(k)$ occurring in some number of trials $(n)$ when the probability of "success" on any one trial is known $(p){ }^{2}$ The probability of a count occurring can be estimated by using expected counts generated from row and column totals, as in a $\chi^{2}$ test (Everitt, 1977). Grayson and Delpech (2003) perform a similar analysis following Everitt (1977:46-48), but here alpha values were calculated by a function written in R ( $R$ Development Core Team, 2009). The benefit of this

2 This analysis was executed in R ( $R$ Development Core Team, 2009) using a function written by Ian G. Robertson (Stanford University) based on a suggestion by James Allison. The same analysis can be done with the TWOWAY function in Kintigh's (2009) Tools for Quantitative Archaeology. approach is its ability to discriminate between multiple bone counts that contribute to variation in a single measure, of particular interest in this case, being the differential effect of deer (or artiodactyl) and rabbit (or leporid) bone on indices of taxonomic abundance.

In other cases where the means from two non-normally distributed samples (or components) with unequal sums were being compared, a Kruskal-Wallis rank sum test was performed ( $\mathrm{R}$ Development Core Team, 2009). As this test makes no assumptions about the distribution of cases, it is more appropriate than common tests (e.g., a $t$-test) for data that cannot be shown or assumed to be normally distributed. All analyses were performed in JMP 7.0 (SAS Institute Inc. 2007) and/or R 2.6.2 (R Development Core Team, 2009).

\section{Results}

Of 18,432 complete bones or bone fragments, 3102 non-intrusive elements were identified to the genus or species level. Of these, 1889 represented terrestrial fauna (Table 2 ). These data indicate that $O$. hemionus remains dominate all but two of the components (9000 $\mathrm{BP}^{*}$ and $1000 \mathrm{BP}^{*}$; Table 3). Prior to testing the hypotheses proposed above, four diagnostic tests of the dataset were run: the first determined if trends in deer remains are consistent across taxonomic levels of identification, the second examined whether or not trends in the relative abundance of deer are correlated with the overall diversity of the resources taken, and the third and fourth tested to see if the relative trends in deer bone counts are only a function of sample size or density mediated attrition.

There is a significant positive relationship between $\mathrm{OI}$ and $\mathrm{AI}$ $\left(R_{L}^{2}=0.0843, p<0.0001\right.$; Table 4$)$, indicating that patterns in the abundance of deer relative to rabbits are consistent across taxonomic levels of identification. There is also a strong positive relationship between OI and the abundance of deer remains relative to all economically significant terrestrial faunal remains (\% Odocoileus; $R_{L}^{2}=0.0820, p<0.0001$ ) suggesting that the variation in deer remains is consistent relative to all other terrestrial taxa, not just rabbit remains. These results indicate that the diachronic patterns observed in these data are not an artifact of a single index. 
Table 3

Abundance and diversity indices for economically significant terrestrial fauna per component.

\begin{tabular}{|c|c|c|c|c|c|c|c|c|c|c|c|c|}
\hline Index & Measure & 500 & 1000 & 1500 & 2500 & 3000 & 5000 & 5500 & 7000 & 7500 & 8500 & 9000 \\
\hline OI & Odocoileus/Sylvilagus & 0.85 & 0.11 & 0.74 & 0.80 & 0.82 & 0.90 & 0.76 & 0.72 & 0.68 & 0.57 & 0.24 \\
\hline AI & Artiodactyl/Leporid & 0.91 & 0.22 & 0.82 & 0.86 & 0.88 & 0.94 & 0.84 & 0.85 & 0.76 & 0.67 & 0.30 \\
\hline$\%$ Odocoileus & Odocoileus/sum NISP & 0.76 & 0.09 & 0.64 & 0.75 & 0.6 & 0.9 & 0.72 & 0.72 & 0.62 & 0.5 & 0.19 \\
\hline$S(\Sigma \mathrm{TAXA})$ & Diversity (richness) & 9 & 8 & 17 & 8 & 4 & 2 & 7 & 2 & 6 & 3 & 5 \\
\hline Margalef's $\mathrm{s}^{\mathrm{a}}$ & Diversity (richness) & 1.60 & 1.60 & 2.38 & 1.24 & 1.11 & 0.43 & 1.07 & 0.31 & 1.14 & 0.96 & 1.31 \\
\hline$\left(1 /\right.$ Simpson's $^{\mathrm{a}}$ & Diversity (evenness) & 1.6 & 2.2 & 2.2 & 1.7 & 2.6 & 1.3 & 1.7 & 1.7 & 2.1 & 3.1 & 2.5 \\
\hline
\end{tabular}

a See Magurran $(1988,2004)$.

Table 4

Summary of results from the generalized linear models.

\begin{tabular}{|c|c|c|c|c|c|c|c|c|}
\hline Dependent variable & Independent variable & DF & Estimate & $\chi^{2}\left(G_{M}\right)$ & $D_{0}$ & $R_{L}^{2}$ & $p$ & \\
\hline OI & $\mathrm{AI}$ & 1 & 5.18 & 184.75 & 2192.81 & 0.0843 & $<0.0001$ & $* \leftarrow$ \\
\hline OI & $\%$ Odocoileus & 1 & 4.92 & 179.86 & 2192.81 & 0.0820 & $<0.0001$ & $* \leftarrow$ \\
\hline OI & Simpson's & 1 & -1.87 & 197.26 & 2192.81 & 0.0900 & $<0.0001$ & $* \leftarrow$ \\
\hline OI & Total NISP & 1 & $<0.01$ & 0.18 & 2192.81 & 0.0001 & 0.6686 & \\
\hline Mean bone density & $\mathrm{BP}^{*}$ midpoint & 1 & $<0.01$ & 0.92 & 2509.63 & 0.0004 & 0.3368 & \\
\hline Mean bone density & Mean (S)FUI & 1 & $<0.01$ & 0.04 & 650.86 & 0.0001 & 0.8499 & \\
\hline $\mathrm{OI}$ & $\mathrm{BP}^{*}$ midpoint & 1 & $<0.01$ & 2.96 & 2192.81 & 0.0013 & 0.0856 & \\
\hline $\mathrm{OI}^{\mathrm{a}}$ & $\mathrm{BP}^{*}$ midpoint & 1 & $<0.01$ & 14.10 & 1996.39 & 0.0071 & 0.0002 & $* \leftarrow$ \\
\hline
\end{tabular}

a Model with the Middle-Late Transition component (1000 $\mathrm{BP}^{*}$ ) excluded from the analysis.

As predicted by the PCM, the evenness component of diversity (Simpson's Index) has a significant and negative effect on OI $\left(R_{L}^{2}=0.0900, p<0.0001\right)$. This shows that when the relative abundance of deer decreases relative to rabbits, the overall evenness of terrestrial prey acquired increases. In other words, when the relative abundance of deer declines, foragers are not focusing on another single species, but on a more even distribution of many species. This suggests that, at least in this case, deer were highly ranked prey because a decline in their relative abundance leads to an overall increase in proportion of all other terrestrial prey taken on encounter. Whether this is the result of increasing bout failures with deer or simply fewer encounters, this result matches the prediction derived from the PCM, showing that a decrease in the relative abundance of highly ranked prey is also associated with an increasing diversity (evenness) in the number of resources taken.

If patterns in the relative abundance of large game are only epiphenomenal to problems with sample size, then measures of prey abundance should exhibit strong co-linearity with total assemblage size (Grayson, 1981, 1984; see also Orton, 2005). Here, there is no significant relationship between sample size (total NISP) and OI $\left(R_{L}^{2}=0.0001, p=0.7156\right.$; Table 4$)$, indicating that patterns in the abundance of large game are not an artifact of sampling.

If variation in the relative abundance of large prey is due to taphonomic processes, then the mean density of artiodactyl bones in should increase with age (Grayson, 1988, 1989; Lyman, 1984, $1985,1994)$. An analysis of variance on 486 non-repeatable elements indicates that there is not a significant relationship between mean artiodactyl bone density and time ( $p=0.7277$; see Table 5$)$. As these data are technically non-parametric (Shapiro-Wilk $W=0.92, p<0.0001)$, this result was also checked with a binomial-logit GLM $\left(R_{L}^{2}=0.0004, p=0.3368\right)$, which confirmed the result. There was also no significant relationship between (S)FUI values and mean bulk density of artiodactyl bones $\left(R_{L}^{2}=0.0001\right.$, $p=0.8499$ ). This suggests that density mediated attrition does not contribute significantly to temporal variation in either the abundance of artiodactyls or variation in (S)FUI values.

\section{Hypothesis 1: resource depression}

The logic of the resource depression hypothesis is derived from the PCM, which, when supplemented with the assumption that
Table 5

Mean bulk artiodactyl bone density per component.

\begin{tabular}{rrl}
\hline \multicolumn{1}{c}{ BP $^{*}$} & \multicolumn{1}{c}{ Mean bulk density } \\
\hline 500 & 73 & 0.40 \\
1000 & 2 & 0.51 \\
1500 & 203 & 0.40 \\
2500 & 88 & 0.38 \\
3000 & 4 & 0.33 \\
5000 & 3 & 0.39 \\
5500 & 73 & 0.39 \\
7000 & 13 & 0.37 \\
7500 & 26 & 0.38 \\
8500 & 1 & 0.25 \\
9000 & 0 & - \\
\hline
\end{tabular}

a Values assigned following Grayson (1988).

prey body size scales with return rate (see above), leads to the prediction that large prey (in this case deer) should always be pursued on encounter to the exclusion of other prey until the encounter rate with large prey declines to a point where the overall return rate (search and pursuit; $\mathrm{E} / \mathrm{T}$ ) is lower than the post-encounter $(\mathrm{e} / \mathrm{h})$ return rate for smaller prey; that is, when the inclusion of lower ranked prey increases the overall return rate. If human predation causes large prey populations to decline, then this process should happen overtime as a function of increased hunting pressure. Archaeologically, this hypothesis has been tested with bone count data, large prey age structure, and through an examination of differential butchering.

The first prediction of the resource depression hypothesis $(P 1 a)$ states that if the abundance of large game varies in response to human predation pressure, then sustained human exploitation should lead to a decrease in the proportion of large prey remains relative to small prey remains over time (e.g., Bayham, 1979; Broughton, 1994; Cannon, 2000, 2003; Janetski, 1997; see also Grayson, 2001). A test of this prediction shows that there is not a significant relationship between Odocoileus index values and time $\left(R_{L}^{2}=0.0013, p<0.0856\right.$; Table 4$)$, indicating that there is no evidence for a decrease in the proportion of deer remains to rabbit remains through time. In fact, a close inspection of Fig. 3 suggests that if the Middle-Late Transition $\left(1000 \mathrm{BP}^{*}\right)$ component were ignored, the overall trend throughout the Holocene would be a general increase in the abundance of deer in the Early-Middle 


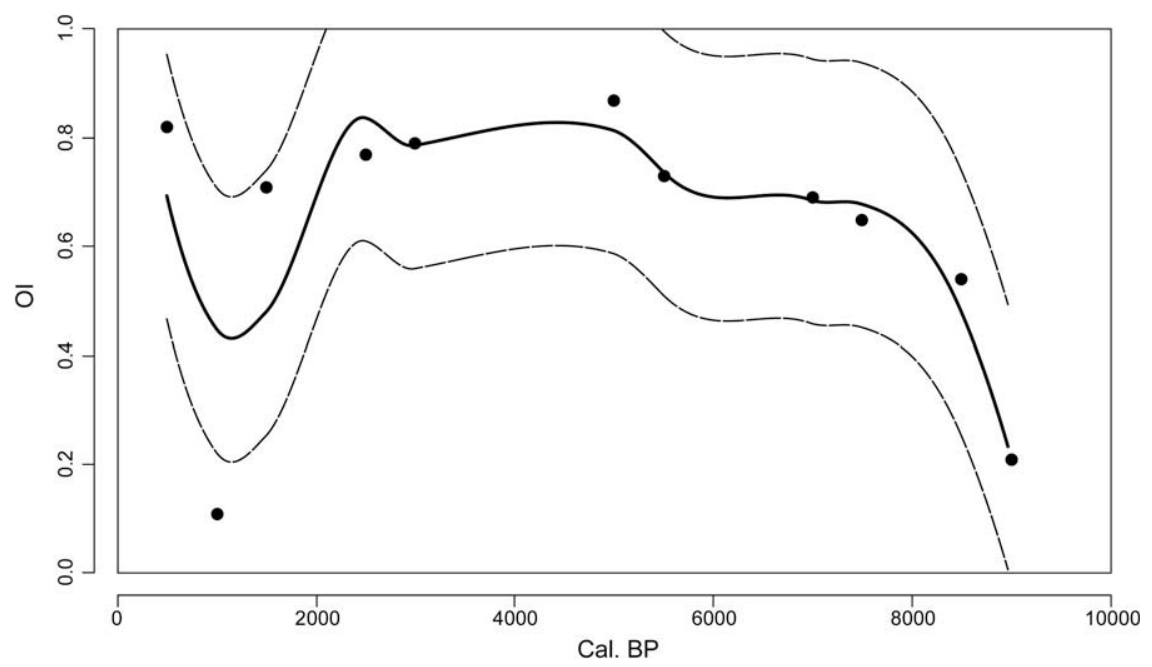

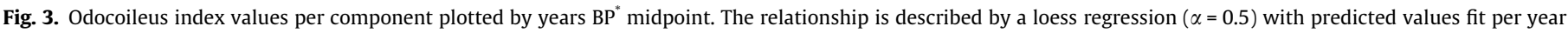
(solid black line) and 95\% confidence intervals based on the standard error of the fit (dashed black lines).

Holocene with relative stability through the Middle-Late Holocene; the opposite of the result predicted by the resource depression hypothesis. Indeed, if the Middle-Late Transition component is excluded from analysis, the proportion of deer relative to rabbits (OI) increases significantly as a function of time $\left(\mathrm{BP}^{*} ; R_{L}^{2}=0.0071\right.$, $p=0.0002$; see Table 4$)$. This finding is not entirely unexpected given Whitaker's $(2008,2009)$ recent work which suggests that, based on their life-history traits, deer may be much less susceptible to anthropogenic resource depression than previously thought. With the Middle-Late Transition component excluded, this trend resembles at least superficially patterns described by Hildebrandt and McGuire (2002) who explain the departure from the predictions of the resource depression hypothesis with reference to the prestige hunting hypothesis; however, further analysis is required to examine if deer acquisition costs also increase collinearly with the increase in deer relative to rabbits (see below).

Broughton (1995, 1997, 1999, 2002) and others (Stiner et al., 2000; Butler, 2000) suggest that an examination of prey age structure can also provide or corroborate evidence of resource depression: if prey age profiles indicate a significant shift in the exploited age structure of prey, then these changes are probably due to human overexploitation leading to a change in the available prey. A test of the second resource depression hypothesis $(P 1 b)$ supports the results from $P 1 a$, showing that there is no significant change in the age structure of artiodactyls exploited through time $\left(\chi^{2}=17.971, p=0.5152\right.$; Table 6$)$. This result shows that the age structure of deer that hunters acquired did not vary through time any more than could be due to chance.

Cannon $(2000,2003)$ proposed a third measure of resource depression, suggesting that anthropogenic overexploitation could be "invisible" when examined by bone counts, but could be identified by the food utility of elements deposited in archaeological sites. Based on the logic of the PCM and CPF models, $(P 1 c)$ if local resource depression forces foragers to travel further to acquire large prey, an acquired carcass will be field processed (butchered) to a greater extent in order to maximize a single load transported back to a central place, resulting in an increase in (S)FUI values. The results of a Kruskal-Wallis test show that the mean (S)FUI values per component differ significantly from one another $\left(\chi^{2}=14.69\right.$, $D F=7, p=0.0402$; Table 7). However, this result is entirely dependent on the Late Period component centered at $500 \mathrm{BP}^{*}$. When this component is excluded from the analysis, the other components do not differ significantly from one another $\left(\chi^{2}=5.59, D F=6\right.$, $p=0.4702$ ), nor do they differ from a null set of artiodactyl ele-
Table 6

Representation of artiodactyl elements identifiable by age per component. Counts are observed values, expected values were generated based on the $\chi^{2}$ test.

\begin{tabular}{|c|c|c|c|c|c|c|c|}
\hline \multirow[t]{2}{*}{$\mathrm{BP}^{*}$} & \multicolumn{2}{|l|}{ Adult } & \multicolumn{2}{|c|}{ Juvenile } & \multicolumn{2}{|c|}{ Sub-adult } & \multirow[t]{2}{*}{ Total } \\
\hline & Count & Expected & Count & Expected & Count & Expected & \\
\hline 500 & 102 & 101.66 & 15 & 13.63 & 4 & 5.71 & 121 \\
\hline 1000 & 4 & 4.20 & 1 & 0.56 & 0 & 0.24 & 5 \\
\hline 1500 & 352 & 339.41 & 35 & 45.52 & 17 & 19.07 & 404 \\
\hline 2500 & 130 & 133.58 & 18 & 17.91 & 11 & 7.51 & 159 \\
\hline 3000 & 6 & 5.04 & 0 & 0.68 & 0 & 0.28 & 6 \\
\hline 5000 & 4 & 4.20 & 1 & 0.56 & 0 & 0.24 & 5 \\
\hline 5500 & 144 & 150.38 & 24 & 20.17 & 11 & 8.45 & 179 \\
\hline 7000 & 10 & 12.60 & 4 & 1.69 & 1 & 0.71 & 15 \\
\hline 7500 & 28 & 28.56 & 6 & 3.83 & 0 & 1.61 & 34 \\
\hline 8500 & 1 & 0.84 & 0 & 0.11 & 0 & 0.05 & 1 \\
\hline 9000 & 2 & 2.52 & 1 & 0.34 & 0 & 0.14 & 3 \\
\hline Total & 783 & & 105 & & 44 & & 932 \\
\hline
\end{tabular}

$\chi^{2}=17.971, p=0.5152$.

Table 7

Summary of artiodactyl (S)FUI values per component and the results of a KruskalWallis test comparing (S)FUI values from each component to the (S)FUI values from a null (complete) set of elements.

\begin{tabular}{lrllll}
\hline BP $^{*}$ & $N$ & Mean (S)FUI & $\chi^{2}$ & $D F$ & $P$ \\
\hline 500 & 53 & 29.40 & 9.75 & 1 & $0.0018^{*}$ \\
1000 & 2 & 21.10 & 1.54 & 1 & 0.2144 \\
1500 & 172 & 37.94 & 1.38 & 1 & 0.2400 \\
2500 & 75 & 36.46 & 2.80 & 1 & 0.0940 \\
3000 & 3 & 57.97 & 0.64 & 1 & 0.4242 \\
5000 & 1 & 37.00 & - & - & - \\
5500 & 62 & 39.02 & 0.80 & 1 & 0.3713 \\
7000 & 7 & 32.21 & 0.80 & 1 & 0.3715 \\
7500 & 20 & 41.85 & 0.00 & 1 & 0.9951 \\
8500 & 1 & 19.40 & - & - & - \\
9000 & 0 & - & - & - & - \\
Complete & 118 & 38.22 & - & - & -
\end{tabular}

Note: because the components centered at $5000 \mathrm{BP}^{*}$ and $8500 \mathrm{BP}^{*}$ only had a single specimen to which (S)FUI values could be assigned and the $9000 \mathrm{BP}^{*}$ component had none, they were excluded from this analysis.

ments (i.e., a complete skeleton; see Table 7). This suggests that prehistoric foragers along the Pecho Coast did not differentially butcher and transport artiodactyl carcasses until the Late Period, when mean (S)FUI values are significantly lower than a null set 
of elements ( $\chi^{2}=9.75, D F=1, p=0.0018$; see Table 7 ). This implies that during the Late Period, foragers were selectively butchering and returning lower utility artiodactyl remains to the central place than would be expected by chance alone. While this result is the opposite of Cannon's (2003) resource depression prediction, it is still indicative of differential processing, potentially resulting from foragers stripping high value meat from high value bones in order to transport carcasses over longer distances (see Lupo, 2001, 2006; O'Connell et al., 1988). This suggests that artiodactyl populations were being locally suppressed by human hunting during the Late Period.

\section{Hypothesis 2: prestige hunting}

Cannon's (2003) model also provides a set of predictions that can be used to test the prestige hunting hypothesis. Initially building on ethnographic work by Hawkes $(1991,1993)$ and others, Hildebrandt and McGuire (2002, see also Hildebrandt and McGuire, 2003) proposed that the abundance of large prey varies through time in response to changes in social organization which alter the rewards associated with acquiring large prey. Later cast in the framework of Costly Signaling Theory (McGuire and Hildebrandt, 2005; McGuire et al., 2007; see Bliege Bird, 2007; Bliege Bird and Smith, 2005; Bliege Bird et al., 2001; Hawkes and Bliege Bird, 2002; Smith and Bliege Bird, 2000; Smith, 2004; Smith et al., 2000; Zahavi, 1975), the prestige hunting hypothesis predicts that an increase in group size or the frequency of social aggregations will lead to a synchronous increase in the benefits individuals gain from acquiring large game: as group size increases, a successful hunters' audience increases as well, providing a greater potential payoff for signaling strategies. While this may lead to an overall decrease in the archaeological abundance of large prey (see Codding and Jones, 2007b; Jones and Codding, 2010), it is hypothesized by Hildebrandt and McGuire (2002, 2003; McGuire and Hildebrandt, 2005) that the relative abundance of large taxa will increase, leading in turn to a relative increase in acquisition costs because foragers engaged in a signaling strategy should differentially seek out larger prey, ultimately having to travel further to encounter artiodactyls (McGuire et al., 2007). As predicted by the $\mathrm{CPF}$, foragers should then spend a greater amount of time differentially processing acquired prey to increase the utility of a single load returned to the central place. In the terms of Cannon's (2003) model, (P2a) an increase in the relative abundance of large prey coupled with $(P 2 b)$ an increase in mean (S)FUI could support this hypothesis (see also Jones et al., 2008a).

As shown above, there is no significant correlation between OI and time, showing that there is no diachronic increase in OI as predicted by the prestige hunting hypothesis (see Table 4). However, as noted above, when the decrease in OI associated with the Middle-Late Transition $\left(1000 \mathrm{BP}^{*}\right)$ component is ignored, the trend does show a significant increase in the proportion of deer relative to rabbits through time. This is marked by a low abundance of deer in the two early Holocene components that later increases in the Early-Mid Holocene. Although this general trend is predicted by the prestige hunting hypothesis (Hildebrandt and McGuire, 2002), it could also be a function of environmental changes that benefited deer populations in the leading to a higher encounter rate with deer (Byers and Broughton, 2004). To support the prestige hunting hypothesis, the data would have to show an increase in deer acquisition (i.e., an increase in OI) in despite of high acquisition costs.

However, as shown through the analysis of butchering and transport practices above, there is no change in acquisition costs through these time periods. In fact, the deer remains deposited during this transition do not differ significantly from a complete deer carcass, suggesting that deer were only acquired at low costs within a distance where the transport of nearly entire carcass was feasible. This implies that foragers acquired deer when locally available near their central place, and did not incur greater costs to travel long distances (passing over other resources in the process) to differentially acquire deer.

The only evidence for differential butchering possibly consistent with the prestige hunting hypothesis occurs not during the Early-Mid Holocene increase in deer, but in the Late Holocene. The Late Period component (centered at $500 \mathrm{BP}^{*}$ ) shows evidence of differential butchering and transport, suggesting a more logistic hunting strategy than during other time periods (Table 7). This also implies greater acquisition costs during this time period. While not proving that male hunters gained prestige from hunting large game in the daily business of foraging, these data suggest that foragers were acquiring deer at a higher overall cost; if such costs are paired with an increase in deer remains relative to rabbits, this may support the prestige hunting hypothesis. Further clarification of these trends may be found through tests of the environmental stochasticity hypothesis.

\section{Hypothesis 3: environmental stochasticity}

If the abundance of large prey varies as a result of large-scale environmental factors, then relative measures of prey abundance should scale with stochastic fluctuations in paleoclimate that differentially impact one prey type over another. Contemporary studies of deer ecology have shown that population densities decline with prolonged aridity (Lawrence et al., 2004; Mackie et al., 1982, 2003). Rabbits, like most other fast-breeding small mammals, are less affected by large-scale trends in precipitation than slow-breeding ungulates. If this is the case, $(P 3)$ then particularly arid or seasonally arid time periods should be associated with archaeological signatures that show significantly less deer and significantly more rabbit remains resulting from declines in the encounter rates with deer. Based on previous research in western North America, this should be the case in the Early to Mid Holocene (see Byers and Broughton, 2004; Byers et al., 2005; Kennett et al., 2007) and during the Middle-Late Transition component centered at $1000 \mathrm{BP}^{*}$ which is associated with the Medieval Climatic Anomaly (aka the Medieval Warm Period; see Brunelle and Anderson, 2003; Graumlich, 1993; Jones and Schwitalla, 2008; Jones et al., 1999; Kennett and Bottman, 2006; Pilloud, 2006; Raab and Larson, 1997; Stine, 1994, 2000; Wiess, 2002).

Examining the probability that each deer and rabbit bone count would occur shows that both predictions are upheld, with the earliest Holocene and Middle-Late Transition components showing lower deer bone counts and higher rabbit bone counts than would be expected by chance alone (Table 8 ). These results show that $\mathrm{OI}$ values for earliest component centered at $9000 \mathrm{BP}^{*}$ are low as result of significantly fewer deer remains than expected $(p=0.005)$ and significantly more rabbit remains than expected $(p=0.0007)$, suggesting that climate differentially impacted deer populations in the Early Holocene. However, the relative abundance of deer increases dramatically after this component. That the predicted increase in deer abundance occurred much earlier along the Pecho Coast than elsewhere in western North America (see e.g., Broughton et al., 2008), suggests an important local difference in precipitation, water availability or seasonality; as others have suggested (see Hockett, 2005; Jones and Waugh, 1997; Zeanah, 2004) such local variability may be more important than large scale trends. The second specific prediction was also met for the Middle-Late Transition component centered at $1000 \mathrm{BP}^{*}$, which shows significantly fewer deer bones than expected $(p<0.0001)$ and significantly more rabbit bones than expected $(p<0.0001)$. This suggests that $\mathrm{OI}$ values during this time represent the impact of the 
Table 8

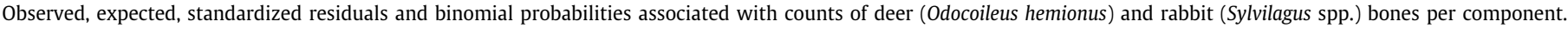
Significant values are marked with an asterisk. The direction (positive or negative) of the significant trends are shown by the standardized residuals.

\begin{tabular}{|c|c|c|c|c|c|c|c|c|c|c|}
\hline \multirow[t]{2}{*}{$\mathrm{BP}^{*}$} & \multicolumn{5}{|c|}{ Deer (Odocoileus hemionus) } & \multicolumn{5}{|c|}{ Rabbits (Sylvilagus spp.) } \\
\hline & Observed & Expected & Residual & Probability & & Observed & Expected & Residual & Probability & \\
\hline 500 & 213 & 185.34 & 2.03 & 0.0187 & $* \leftarrow$ & 38 & 65.66 & -3.41 & 0.0001 & $* \leftarrow$ \\
\hline 1000 & 7 & 43.57 & -5.54 & $<0.0001$ & $* \leftarrow$ & 52 & 15.43 & 9.31 & $<0.0001$ & $* \leftarrow$ \\
\hline 1500 & 522 & 522.05 & -0.00 & 0.5107 & & 185 & 184.95 & 0.00 & 0.5098 & \\
\hline 2500 & 209 & 192.72 & 1.17 & 0.1144 & & 52 & 68.28 & -1.97 & 0.0223 & $* \leftarrow$ \\
\hline 3000 & 9 & 8.12 & 0.31 & 0.4246 & & 2 & 2.88 & -0.52 & 0.4510 & \\
\hline 5000 & 9 & 7.38 & 0.59 & 0.3220 & & 1 & 2.62 & -1.00 & 0.2641 & \\
\hline 5500 & 198 & 193.46 & 0.33 & 0.3755 & & 64 & 68.54 & -0.55 & 0.3143 & \\
\hline 7000 & 18 & 18.46 & -0.11 & 0.5190 & & 7 & 6.54 & 0.18 & 0.4799 & \\
\hline 7500 & 49 & 53.17 & -0.57 & 0.3104 & & 23 & 18.83 & 0.96 & 0.1947 & \\
\hline 8500 & 4 & 5.17 & -0.51 & 0.4111 & & 3 & 1.83 & 0.86 & 0.2777 & \\
\hline 9000 & 4 & 12.55 & -2.41 & 0.0050 & $* \leftarrow$ & 13 & 4.45 & 4.06 & 0.0007 & $* \leftarrow$ \\
\hline
\end{tabular}

$\chi^{2}=165.06, p=0.0005$

Medieval Climatic Anomaly on local deer populations which caused a decline in hunters' encounter and success rates.

Two other statistically significant patterns, not clearly predicted by the environmental stochasticity hypothesis, also appear (see Table 8). The first significant pattern shows fewer rabbits than expected at $2500 \mathrm{BP}^{*}(p=0.0223)$ without a significant accompanying difference in deer remains. While significant, this trend does not appear to have a discernable interpretation when viewed in association with other trends and does not have clear implications for any of the other hypotheses tested here; although, it could indicate that hunting bout success with deer during this time was so high that foragers spent little time pursuing rabbits. The other significant pattern occurs in the Late Period component centered at $500 \mathrm{BP}^{*}$, where there are significantly more deer remains than expected ( $p=0.0187$ ) and significantly fewer rabbit bones than expected $(p=0.0001)$. When viewed in context with the evidence for differential butchering during this time period (Table 7) this result seems to support both the resource depression and the prestige hunting hypotheses which has interesting implications for the interactions between localized resource depression and the social role of hunting.

\section{Discussion and conclusion}

Analyses of the Pecho Coast assemblages suggest that diachronic patterns in deer abundance were neither a product of sampling size nor density mediated attrition. Moreover, the relative patterns in the importance of deer were robust across all levels of taxonomic identification and co-vary negatively with measures of evenness. As predicted by the PCM, this suggests that deer were a highly ranked prey item and/or that when hunting bout success with deer was relatively reliable, foragers spent little or no time pursuing other terrestrial resources. Of the three hypotheses proposed to explain diachronic variation in the abundance of large terrestrial prey, findings suggest that climatically-mediated prey choice is the most significant factor. Throughout most of the Holocene, foragers along the Pecho Coast exploited a robust population of deer, but against this backdrop, three components stand out as anomalous.

First, the component centered at $9000 \mathrm{BP}^{*}$ represents the behavior of some of the first inhabitants of this region. Data from this early Millingstone component is marked by relatively low deer remains relative to rabbits, a pattern that has been noted elsewhere in the region (Lebow et al., 2007; Stevens et al., 2004) and elsewhere in California (Erlandson, 1994; McGuire and Hildebrandt, 1994; but see Hildebrandt and Carpenter, 2006:290). When the data showing significantly fewer deer remains and more rabbit re- mains than expected is coupled with previous paleoenvironmental work, this pattern is best explained by evidence of climatically depressed deer populations, as suggested by other studies in western North America (e.g., Broughton et al., 2008; Byers and Broughton, 2004; Byers et al., 2005); although, the subsequent increase in deer seems to occur earlier on the Pecho Coast than elsewhere in western North America. As there is no evidence for changes in settlement or mobility during this transition (Jones and Codding, 2010; Jones et al., 2008a, 2009; Table 7), this change in the abundance of deer is probably due to local ecological differences that affected deer populations. However, as noted by other researchers, patterns in the Early Holocene do suggest a difference in foragers' gender division of labor than what is evident during the Middle and Late Holocene; specifically, early California foragers may have experienced greater overlap between men's and women's prey choice due to the low abundance of larger prey (Hildebrandt and McGuire, 2002; Jones, 1996; McGuire and Hildebrandt, 1994; Zeanah, 2004; but see Kuhn and Stiner, 2006). Immediately following this time period, the abundance of deer increases, and remains relatively stable for the majority of the Holocene until about $1000 \mathrm{BP}^{*}$ (see Fig. 3).

The Middle-Late Transition occupation centered at $1000 \mathrm{BP}^{*}$ is the second component that stands out relative to all of the others. It is marked by the lowest OI values of all the assemblages, driven by both deer bone counts that are significantly lower than expected and rabbit bone counts that are significantly higher than expected (Table 8 ). As deer are impacted more severely than rabbits by droughts, this trend is interpreted as a local expression of the Medieval Climatic Anomaly; which has been shown to have severe impacts throughout California (Jones et al., 1999; Jones and Schwitalla, 2008). The restructuring of the terrestrial resource base caused by the Medieval Climatic Anomaly may also have driven foragers to acquire prey more frequently in marine patches, as suggested by other work along the California coastline where evidence shows that foragers relied increasingly on the marine environment to dampen the effects of a depressed terrestrial ecosystem (e.g., Jones and Kennett, 1999; Kennett, 2005; Kennett and Kennett, 2000). Overall, these patterns suggest that the Medieval Climatic Anomaly initiated a dramatic shift in the available resources and perhaps altered human population densities, shifting conditions towards something similar to what foragers experienced in the Early Holocene. In response to these changes, it appears that coastal California foragers rapidly adapted by altering their subsistence strategies to the new environment. Such environmental changes may also have influenced variation in gender division of foraging labor: if men were primarily responsible for acquiring deer and environmental conditions caused deer populations to collapse which reduced both encounter and bout success rates with deer; 
then men's overall contribution to subsistence may have decreased (see Bliege Bird et al., 2009), or men may have targeted alternative resources. While men's continued pursuit of deer may have been rewarded with increased social benefits (including prestige) due to an increase in acquisition costs, such a strategy could not have been maintained by a large portion of the population and thus, could not have contributed significantly to these faunal remains (see Codding and Jones, 2007b).

Immediately following this interval of anomalous climate, conditions superficially return to the former pattern showing a high proportion of deer remains relative to rabbits. On closer inspection, however, the Late Period component centered at $500 \mathrm{BP}^{*}$ represents the third atypical assemblage. During this time rabbit bone counts were significantly lower than expected and deer bone counts were significantly higher than expected. Moreover, (S)FUI values indicate that these bones were of lower overall food utility than a complete deer carcass, indicating higher transport and search costs. While variability in the previous time periods supports the environmental stochasticity hypothesis, these changes in the final component suggest an interaction between the other two hypotheses. First, the changes in butchering practices suggest that foragers had to travel further in order to successfully acquire deer. This pattern may be a product of more permanent human settlements along the Pecho Coast in the Late Holocene (see Jones et al., 2008b) which either increased deer mortality rates, or led to behavioral resource depression where deer avoided areas frequented by human hunters (see Charnov et al., 1976). The bone count data suggests the latter, as foragers acquired more deer than expected during the late period, suggesting that any negative impact foragers may have had on deer populations was only a local phenomena and acquisition was still possible by incurring higher travel costs. Such costs may have been mitigated by increased social benefits to those who could successfully acquire larger prey, as predicted by the prestige hunting hypothesis (Hildebrandt and McGuire, 2002; McGuire and Hildebrandt, 2005). These interactions suggest an interesting dynamic between ecological, demographic and social factors where human populations depressed local deer populations, simultaneously increasing the benefits and costs of hunting deer.

These combined impacts may be due to introduced technology that increased return rates or hunting bout success rates with deer. Grayson and Cannon (1999) discuss how archaeologists utilizing foraging models tend to hold the impacts of changes in technology on return rates constant through time, despite evidence for profound affects of technology on prey acquisition (e.g., Bettinger et al., 2006; Lupo and Schmitt, 2002, 2005; O'Connell and Hawkes, 1984; O'Connell and Marshall, 1989; Winterhalder, 1981). As the Late Holocene marks dramatic changes in flake stone technology along California's Central Coast, including changes in projectile point morphology suggesting the adoption of the bow and arrow (see Jones et al., 2007; Stevens and Codding, 2009), the unexpected increase in deer remains may be the result of changing return rates and/or pursuit success rates resulting from newly introduced weapon technology. However, this may require a better understanding of how exactly changes in projectile technology affect hunting return and/or success rates with deer and other large ungulates.

Other than these anomalous departures from the generalized Holocene pattern, the relative homogeneity of the other assemblages has interesting implications for understanding prehistoric human-prey interactions. These data show that foragers along the Pecho Coast were able to exploit a large, stable population of deer throughout the Holocene without negatively impacting or suppressing their populations. However, this should not be taken as evidence of conservation-oriented behavior, especially since an extreme case of the opposite pattern is also evident in the faunal remains from these sites: human caused extinction of the flightless duck (Chendytes lawi; see Jones et al., 2008a,c). Rather, these results imply that even over long time periods, human-prey interactions involving large ungulate species may be more regulated by density independent factors (i.e., factors unrelated to predator-prey population dynamics) than density dependent ones (i.e., random external effects). Specifically, while we should predict that increases in human population densities and decreases in foraging mobility (effectively increasing the number of foragers per unit area) should negatively impact prey populations (see Winterhalder and Lu, 1997), possibly leaving clear archaeological signatures of such a process (e.g., Stutz et al., 2009), we should also expect that different prey species should respond in different ways to human predation depending on their behavior and life-history characteristics (Whitaker, 2008, 2009). Those species with relatively "faster" life histories should be less affected than those with "slower" ones. While deer should be more susceptible to overhunting than rabbits, they may be less so than some marine mammals (e.g., California sea lions [Zalophus californianus]) and even other terrestrial mammals (e.g., elk [Cervus elaphus]) which has important implications for the predicted effects of human hunting on prey populations (Whitaker, 2008, 2009). There may be requisite threshold levels in human population densities resulting in sustained predation pressure before deer populations can be severely depressed by human hunting. Given that elk should be more susceptible to overexploitation than deer and that their populations did not disappear from regional archaeological faunas until ca. $1500 \mathrm{BP}^{*}$ (Table 1; see also Jones and Codding, 2010; Lebow et al., 2005), prehistoric human populations in the region may have not reached such a threshold. If this is the case, it may be that the local extirpation of elk resulted from the extreme aridity associated with the Medieval Climatic Anomaly; however, a more regional systematic analysis is required to answer this question with certainty.

These findings from the Pecho Coast suggest that throughout the Holocene, human hunting pressure and fluctuations in the social role of large game hunting had less of an impact on diachronic patterns in relative deer abundance than did stochastic environmental factors that differentially impacted deer over rabbits (e.g., the Medieval Climatic Anomaly). In other words, when controlling for spatial variability, temporal variation in the abundance of large prey relative to small prey is best described as climatically-mediated prey choice. This does not, however, mean that humans had no impacts on prey populations or that hunting carries no prestige; indeed, it may be that the overriding impact of climatic variation on prey density simply masks or drowns out important demographic and social variation liked to human-prey interactions. As such, it may be that such patterning is not easily visible at archaeological time scales.

While the trends examined here may not hold in other regions of western North America, these results suggest that (1) any single hypothesis is unlikely to provide an adequate explanation of prehistoric variability in human hunting decisions and (2) incorporating theoretical and statistical models that allow (rather than ignore) stochastic variability may be critically important in explaining diachronic patterns in prey choice. By systematically approaching zooarchaeological data in such a way, researchers may ultimately come to a better understanding of the interrelated articulations between human behavioral variability, ecological dynamics and specific moments in prehistory.

\section{Acknowledgments}

We owe an enormous debt of gratitude to Roberta Greenwood for running such impressive excavations in 1968, and to Elise Wheeler, Nathan E. Stevens and the Cal Poly, SLO field and lab classes from 2004 to 2008 -this paper would not exist without their 
hard work. Analysis benefited tremendously from the advice and assistance of Richard G. Klein, James Holland Jones, Mike Cannon and especially Ian G. Robertson. Douglas W. Bird, Rebecca Bliege Bird, Nathan E. Stevens, Ian Hodder, Bill Hildebrandt and an anonymous reviewer read previous versions of this paper - we are deeply indebted to them for their thoughtful comments which stimulated thinking and greatly improved the final product. Funding for this work came from the California Department of Parks and Recreation, a California Sea Grant, and a National Science Foundation Graduate Research Fellowship. Any mistakes in fact or judgment are the sole responsibility of the authors.

\section{References}

Aldenderfer, M., 2006. Costly signaling, the sexual division of labor, and animal domestication in the Andean highlands. In: Kennett, D.J., Winterhalder, B. (Eds.) Behavioral Ecology and the Transition to Agriculture. University of California Press, Berkeley, pp. 167-196.

Bayham, F.E., 1979. Factors influencing the Archaic pattern of animal exploitation. Kiva 44, 219-235.

Bennyhoff, J.A., 1978. Chronology Charts. In: Elsasser, A.B., Development of Regional Prehistoric Cultures. In: Heizer, R.F. (Ed.), California Handbook of North American Indians, vol. 8, W.G. Sturtevant, general ed. Smithsonian Institution, Washington DC, pp. 37-57.

Bennyhoff, J.A., Hughes, R.E., 1987. Shell Bead and Ornament Exchange Networks Between California and the Western Great Basin. American Museum of Natural History Anthropological Papers 64(2).

Bettinger, R.L., 1991. Hunter-Gatherers: Archaeological and Evolutionary Theory Plenum Press, New York.

Bettinger, R.L., 2006. Agriculture, archaeology, and human behavioral ecology. In: Kennett, D.J., Winterhalder, B. (Eds.), Behavioral Ecology and the Transition to Agriculture. University of California Press, Berkeley, pp. 304-322.

Bettinger, R.L., Mahli, R., McCarthy, H., 1997. Central place models of acorn and mussel processing. Journal of Archaeological Science 24, 887-899.

Bettinger, R.L., Winterhalder, B., McElreath, R., 2006. A simple model of technological intensification. Journal of Archaeological Science 33, 538-545.

Binford, L., 1978. Nunamuit Ethnoarchaeology. Academic Press, New York.

Binford, L., 1980. Willow's smoke and dog's tails: hunter-gatherer settlement systems and archaeological site formation. American Antiquity 45, 4-20.

Binford, L., 1983. In Pursuit of the Past: Decoding the Archaeological Record. Thames and Hudson, New York.

Binford, L., 1984. Faunal Remains from Klasies River Mouth. Academic Press, New York.

Bird, D.W., O'Connell, J.F., 2006. Behavioral ecology and archaeology. Journal of Archaeological Research 14, 143-188.

Bird, D.W., Bliege Bird, R., Codding, B.F., 2009. In pursuit of mobile prey: Martu foraging and archaeofaunal interpretation. American Antiquity 74, 3-29.

Bliege Bird, R., 2007. Fishing and the sexual division of labor among the Meriam American Anthropologist 109, 442-451.

Bliege Bird, R., Smith, E.A., 2005. Signaling theory, strategic interaction, and symbolic capital. Current Anthropology 46, 221-248.

Bliege Bird, R., Codding, B.F., Bird, D.W., 2009. What Explains Differences in Men's and Women's Production? Determinants of Gendered Foraging Inequalities among Martu. Human Nature 20, 105-129.

Bliege Bird, R., Smith, E.A., Bird, D.W., 2001. The hunting handicap: costly signaling in male foraging strategies. Behavioral Ecology and Sociobiology 50, 9-19.

Breschini, G.S., Haversat, T., 1988. Archaeological Excavations at CA-SLO-7 and CASLO-8, Diablo Canyon, San Luis Obispo County, California. Coyote Press Archives of California Prehistory, No. 28.

Broughton, J.M., 1994. Declines in foraging efficiency during the late Holocene: the archaeological mammal evidence from San Francisco Bay, California. Journal of Anthropological Archaeology 13, 371-401.

Broughton, J.M., 1997. Widening diet breadth, declining foraging efficiency, and prehistoric harvest pressure: icthyofaunal evidence from the Emeryville Shellmound. Antiquity $71,845-862$.

Broughton, J.M., 1999. Resource Depression and Intensification During the Late Holocene, San Francisco Bay: Evidence from the Emeryville Shellmound Vertebrate Fauna. University of California Anthropological Records 32, Berkeley.

Broughton, J.M., 2002. Prey spatial structure and behavior affect archaeological tests of optimal foraging models: examples from the Emeryville Shellmound vertebrate fauna. World Archaeology 34, 60-83.

Broughton, J.M., Bayham, F.E., 2003. Showing off, foraging models and the ascendance of large game hunting in the California Middle Archaic. American Antiquity 68, 783-789.

Broughton, J.M., Grayson, D.K., 1993. Diet breadth, adaptive change, and the white mountain faunas. Journal of Archaeological Science 20, 331-336.

Broughton, J.M., Byers, D.A., Bryson, R.A., Eckerle, W., Madsen, D.B., 2008. Did climatic seasonality control late quaternary artiodactyl densities in western North America? Quaternary Science Reviews 27, 1916-1937.

Brunelle, A., Anderson, R.S., 2003. Sedimentary charcoal as an indicator of lateHolocene drought in the Sierra Nevada, California, and its relevance to the future. The Holocene 13, 21-28.
Butler, V.L., 2000. Resource depression on the northwest coast of North America. Antiquity 74, 649-661.

Butler, V.L., Campbell, S.K., 2004. Resource intensification and resource depression in the Pacific northwest of North America: a zooarchaeological review. Journal of World Prehistory 18, 327-405.

Byers, D.A., Broughton, J.M., 2004. Holocene environmental change, artiodactyl abundances, and human hunting strategies in the Great Basin. American Antiquity 69, 235-256.

Byers, D.A., Ugan, A., 2005. Should we expect large game specialization in the Late Pleistocene? An optimal foraging perspective on early Paleoindian diet. Journal of Archaeological Science 32, 1624-1640.

Byers, D.A., Smith, C.S., Broughton, J.M., 2005. Holocene artiodactyl population histories and large game hunting in the Wyoming Basin, USA. Journal of Archaeological Science 32, 125-142.

Cannon, M.D., 2000. Large mammal relative abundance in Pithouse and Pueblo Period archaeofaunas from southwestern New Mexico: resource depression in the Mimbres-Mogollon? Journal of Anthropological Archaeology 19, 317-347.

Cannon, M.D., 2001. Archaeofaunal relative abundance, sample size and statistical methods. Journal of Archaeological Science 28, 185-195.

Cannon, M.D., 2003. A model of central place forager prey choice and an application to faunal remains from the Mimbres Valley, New Mexico. Journal of Anthropological Archaeology 22, 1-25.

Cannon, M.D., 2009. When should we expect to see hunting as mating effort? California Archaeology 1, 79-91.

Charnov, E.L., Orians, G.H., Hyatt, K., 1976. Ecological implications of resource depression. The American Naturalist 110, 247-259.

Codding, B.F., Jones, T.L., 2006. The Middle Late Transition on the Central California Coast: Archaeological Salvage at CA-SLO-9, Montaña de Oro State Park, San Luis Obispo County, California. MS on file at the California Historic Resources Information System, Central Coast Information Center, University of California Santa Barbara.

Codding, B.F., Jones, T.L., 2007a. History and behavioral ecology during the middlelate transition on the central California Coast: findings from the Coon Creek Site, CA-SLO-9, San Luis Obispo County. Journal of California and Great Basin Anthropology 27, 23-49.

Codding, B.F., Jones, T.L., 2007b. Man the show-off? or the ascendance of a just-sostory: a comment on recent applications of costly signaling theory in American archaeology. American Antiquity 72, 289-316.

Codding, B.F., Barton, A.M., Hill, E.J., Wheeler, E., Stevens, N.E., Jones, T.L., 2009. The Middle-Late Transition on the Central California Coast: Final Report on Salvage at CA-SLO-9, Montaña de Oro State Park, San Luis Obispo County, California. Occasional Papers of the San Luis Obispo Archaeological Society, No. 19.

Crawley, M.J., 2007. The R Book. John Wiley and Sons, Hoboken.

Dean, R.M., 2007. Hunting intensification and the Hohokam "collapse". Journal of Anthropological Archaeology 26, 109-132.

Erlandson, J.M., 1994. Early Holocene Hunter-Gatherers of the California Coast. Plenum Press, New York.

Everitt, B.S., 1977. The Analysis of Contingency Tables. Chapman and Hall, London. Faraway, J.J., 2006. Extending the Linear Model with R: Generalized Linear, Mixed Effects and Nonparametric Regression Models. Chapman and Hall, New York.

Grayson, D.K., 1978. Minimum numbers and sample size in vertebrate faunal analysis. American Antiquity 43, 53-65.

Grayson, D.K., 1981. The effects of sample size on some derived measures in vertebrate faunal analysis. Journal of Archaeological Science 8, 77-88.

Grayson, D.K., 1984. Quantitative Zooarchaeology: Topics in the Analysis of Archaeological Faunas. Academic Press, New York.

Grayson, D.K., 1988. Danger Cave, Last Supper Cave, and Hanging Rock Shelter: the faunas. Anthropological Papers of the American Museum of Natural History, New York 66, 1-130.

Grayson, D.K., 1989. Bone transport, bone destruction, and reverse utility curves. Journal of Archaeological Science 16, 643-652.

Grayson, D.K., 2001. The archaeological record of human impacts on animal populations. Journal of World Prehistory 15, 1-68.

Grayson, D.K., Cannon, M.D., 1999. Paleoecology and foraging theory in the great basin. In: Beck, C. (Ed.), Models for the Millennium: Great Basin Anthropology Today. University of Utah Press, Salt Lake City, pp. 141-151.

Grayson, D.K., Delpech, F., 1998. Changing diet breadth in the early upper Palaeolithic of southwestern France. Journal of Archaeological Science 25, 1119-1129.

Grayson, D.K., Delpech, F., 2003. Ungulates and the Middle-to-Upper Paleolithic Transition at Grotte XVI (Dordogne, France). Journal of Archaeological Science 30, 1633-1648.

Grayson, D.K., Delpech, F., Rigaud, J., Simek, J.F., 2001. Explaining the development of dietary dominance by a single ungulate taxon at Grotte XVI, Dordogne, France. Journal of Archaeological Science 28, 115-125.

Graumlich, L.J., 1993. A 1000-year tree ring record of temperature and precipitation in the Sierra Nevada. Quaternary Research 39, 249-255.

Greenwood, R.S., 1972. 9000 Years of Prehistory at Diablo Canyon, San Luis Obispo County, California. Occasional Papers of the San Luis Obispo Archaeological Society, No. 7

Griffiths, D., 1975. Prey availability and the food of predators. Ecology 56, 12091214

Hawkes, K., 1991. Showing off: tests of an hypothesis about men's foraging goals. Ethology and Sociobiology 12, 29-54.

Hawkes, K., 1993. Why hunter-gathers work: an ancient version of the problem of public goods. Current Anthropology 34, 341-361. 
Hawkes, K., Bliege Bird, R., 2002. Showing off, handicap signaling, and the evolution of men's work. Evolutionary Anthropology 11, 58-67.

Hildebrandt, W.R., Carpenter, K., 2006. California animals. In: Stanford, D., Smith, B.D., Ubelaker, D.H., Szathmáry, E.J.E. (Eds.), Handbook of North American Indians, Origins, and Population, vol 3. Smithsonian Institution, Washington, DC, pp. 284-291.

Hildebrandt, W.R., McGuire, K.R., 2002. The ascendance of hunting during the California Middle Archaic: an evolutionary perspective. American Antiquity 67, 231-256.

Hildebrandt, W.R., McGuire, K.R., 2003. Large game hunting, gender-differentiated work organization and the role of evolutionary ecology in California and Great Basin prehistory. American Antiquity 68, 790-792.

Hildebrandt, W.R., McGuire, K.R., Rosenthal, J., 2010. Human behavioral ecology and historical contingency: A comment on the Diablo Canyon archaeological record. American Antiquity, in press.

Hockett, B., 2005. Middle and late Holocene hunting in the great basin: a critical review of the debate and future prospects. American Antiquity 70, 713-731.

Hope, A.C.A., 1968. A simplified Monte Carlo significance test procedure. Journal of the Royal Statistical Society, Series B 30, 582-598.

Janetski, J., 1997. Fremont hunting and resource intensification in the eastern Great Basin. Journal of Archaeological Science 24, 1075-1089.

Jochim, M.A., 1976. Hunter-Gatherer Subsistence and Settlement: A Predictive Model. Academic Press, New York.

Jochim, M.A., 1998. A Hunter-Gatherer Landscape: Southwest Germany in the Late Paleolithic and Mesolithic. Plenum Press, New York.

Jones, E.L., 2004. Dietary evenness, prey choice, and human-environment interactions. Journal of Archaeological Science 31, 307-317.

Jones, T.L., 1993. Big sur: a keystone in Central California Culture History. Pacific Coast Archaeological Society Quarterly 29, 1-78.

Jones, T.L., 1996. Mortars, pestles, and division of labor in prehistoric California: a view from big sur. American Antiquity 61, 243-264.

Jones, T.L., 2003. Prehistoric Human Ecology of the Big Sur Coast, California. Berkeley: Contributions of the University of California Archaeological Research Facility No. 61.

Jones, T.L., Codding, B.F., 2010. Historical Contingencies, Issues of scale and flightless fantasies: A response to Hildebrandt et al. American Antiquity, in press.

Jones, T.L., Ferneau, J., 2002. De-intensification along the Central Coast. In: Erlandson, J.M., Jones, T.L. (Eds.), Catalysts to Complexity: Late Holocene Societies of the California Coast. Cotsen Institute of Archaeology, University of California, Los Angeles, pp. 204-231.

Jones, T.L., Kennett, D.J., 1999. Late Holocene sea temperatures along the Central California Coast. Quaternary Research 51, 74-82.

Jones, T.L., Schwitalla, A., 2008. Archaeological Perspectives on the Effects of Medieval Drought in Prehistoric California. In: Proceedings of the 22nd Pacific Climate Workshop. Quaternary International 188, 41-58.

Jones, T.L., Waugh, G., 1997. Climatic consequences or population pragmatism? A middle Holocene prehistory of the central California Coast. In: Erlandson, J., Glassow, M.A. (Eds.), The middle Holocene Along the California Coast. Cotsen Institute of Archaeology, University of California, Los Angeles, pp. 111-128.

Jones, T.L., Garza, S., Porcasi, J.F., Gaeta, J., 2009. Another trans-Holocene sequence from Diablo Canyon: new faunal and radiocarbon findings from CA-SLO-585, San Luis Obispo County, California. Journal of California and Great Basin Anthropology 29, 19-31.

Jones, T.L., Stevens, N.E., Jones, D.A., Fitzgerald, R.T., Hylkema, M.G., 2007. The Central Coast: a mid-latitude milieu. In: Jones, T.L., Klar, K.A. (Eds.), California Prehistory: Colonization Culture and Complexity. Altamira Press, Walnut Creek, California, pp. 125-146.

Jones, T.L., Brown, G.M., Raab, L.M., McVickar, J.L., Spaulding, W.G., Kennett, D.J., York, A., Walker, P.L., 1999. Environmental imperatives reconsidered, demographic crises in Western North America during the medieval climatic anomaly. Current Anthropology 40, 137-170.

Jones, T.L., Fitzgerald, R.T., Kennett, D.J., Miksicek, C.H., Fagan, J.L., Sharp, J., Erlandson, J.M., 2002. The Cross Creek Site, CA-SLO-1797 and its implications for new world colonization. American Antiquity 67, 213-230.

Jones, T.L., Porcasi, J.F., Gaeta, J., Codding, B.F., 2008a. The Diablo Canyon fauna: a coarse-grained record of trans-Holocene foraging from the central California mainland coast. American Antiquity 73, 289-316.

Jones, T.L., Kennett, D.J., Kennett, J.P., Codding, B.F., 2008b. Seasonal stability in late Holocene shellfish harvesting on the central California coast. Journal of Archaeological Science 35, 2286-2294.

Jones, T.L., Porcasi, J.F., Erlandson, J.M., Dallas Jr., H., Wake, T.A., Schwaderer, R., 2008c. The protracted Holocene extinction of California's flightless sea duck, Chendytes lawi and its implications for the pleistocene overkill hypothesis. Proceedings of the National Academy of Science 105, 4105-4108.

Kennett, D.J., 2005. The Island Chumash: Behavioral Ecology of a Maritime Society. University of California Press, Berkeley.

Kennett, D.J., Bottman, T.C., 2006. Oxygen isotope analysis of California Mussel, Mytilus californianus shells from CA-SLO-9. In: Codding, B.F., Jones, T.L. (Eds.) The Middle Late Transition on the central California coast: Archaeological Salvage at CA-SLO-9, Montaña de Oro State Park, San Luis Obispo County, California. MS on file at the California Historic Resources Information System, Central Coast Information Center, University of California, Santa Barbara, pp. 125-136.

Kennett, D.J., Kennett, J.P., 2000. Competitive and cooperative responses to climate instability in Coastal Southern California. American Antiquity 65, 379-395.
Kennett, D.J., Kennett, J.P., Erlandson, J.M., Cannariato, K.G., 2007. Human responses to middle holocene climate change on California's Channel Islands. Quaternary Science Reviews 26, 351-367.

Kieschnick, R., McCullough, B.D., 2003. Regression analysis of variates observed on, $(0,1)$ : percentages, proportions and fractions. Statistical Modeling 3, 193-213.

King, C.D., 1982. The Evolution of Chumash Society: A Comparative Study of Artifacts Used in Social System Maintenance in the Santa Barbara Channel Region before A.D. 1804, Unpublished Ph.D. dissertation, University of California, Davis.

King, C.D., 1990. The Evolution of Chumash Society: A Comparative Study of Artifacts Used in Social System Maintenance in the Santa Barbara Channel Region Before A.D. 1804. Garland Publishing, New York.

Kintigh, K., 2009. Tools for Quantitative Archaeology. Electronic document. <http:// tfqa.com/doc/index.html> (accessed 28.02.2009).

Klein, R.G., 1975. Middle stone age man-animal relationships in Southern Africa: evidence from Die Kelders and Klasies River Mouth. Science 190, 265-267.

Klein, R.G., 1976. The mammalian fauna of the Klasies River Mouth Sites, Southern Cape Province, South Africa. The South African Archaeological Bulletin 31, 7598.

Klein, R.G., 1982. Age, mortality profiles as a means of distinguishing hunted species from scavenged ones in stone age archaeological sites. Paleobiology 8, 151-158.

Klein, R.G., Cruz-Uribe, K., 1984. The Analysis of Animal Bones from Archaeological Sites. University of Chicago Press.

Klein, R.G., Avery, G., Cruz-Uribe, K., Steele, T.E., 2007. The mammalian fauna associated with an archaic hominin skullcap and later Acheulean artifacts at Elandsfontein, Western Cape Province, South Africa. Journal of Human Evolution 52, 164-186.

Kuhn, S.L., Stiner, M.C., 2006. What's a mother to do? The division of labor among Neanderthals and modern humans in Eurasia. Current Anthropology 47, 953980.

Lawrence, R.K., Demarais, S., Relyea, R.A., Haskell, S.P., Ballard, W.B., Clark, T.L., 2004 Desert mule deer survival in Southwest Texas. Journal of Wildlife Management $68,561-569$.

Lebow, C.G., McKim, R.L., Harro, D.R., Munns, A.M., Denardo, C., 2007. Littora Adaptations throughout the Holocene: Archaeological Investigations at the Honda Beach Site, CA-SBA-530. MS on file at the California Historic Resources Information System, Central Coast Information Center, University of California, Santa Barbara.

Lebow, C.G., McKim, R.L., Harro, D.R., Hodges, C.M., Munns, A.M., 2005. Large Game Hunting and Other Paludal Adaptations at Barka Slough: Excavations at CASBA-1010, Vandenberg Air Force Base, Santa Barbara County, California. MS on file at the California Historic Resources Information System, Central Coast Information Center, University of California, Santa Barbara.

Lee, R.B., 1968. What hunters do for a living: or, how to make out on scarce resources. In: Lee, R.B., Devore, I. (Eds.), Man the Hunter. Aldine De Gruyter, New York, pp. 30-55.

Lillard, J.B., Heizer, R.F., Fenenga, F., 1939. An Introduction to the Archaeology of Central California. Department of Anthropology Bulletin 2, Sacramento Junior College, Sacramento.

Lupo, K.D., 2001. Archaeological skeletal part profiles and differential transport: an ethnoarchaeological example from Hadza bone assemblages. Journal of Anthropological Archaeology 20, 361-378.

Lupo, K.D., 2006. What explains the carcass field processing and transport decisions of contemporary hunter-gatherers? Measures of economic anatomy and zooarchaeological skeletal part representation. Journal of Archaeological Method and Theory 13, 19-66.

Lupo, K.D., 2007. Evolutionary foraging models in zooarchaeological analysis: recent applications and future challenges. Journal of Archaeological Research 15, 143189.

Lupo, K.D., Schmitt, D.N., 2002. Upper Paleolithic net-hunting, small prey exploitation and women's work effort: a view from the ethnographic and ethnoarchaeological record of the Congo Basin. Journal of Archaeological Method and Theory 9, 147-179.

Lupo, K.D., Schmitt, D.N., 2005. Small prey hunting technology and zooarchaeological measures of taxonomic diversity and abundance: Ethnoarchaeological evidence from Central African forest foragers. Journal of Anthropological Archaeology 24, 335-353.

Lyman, R.L., 1984. Bone density and differential survivorship of fossil classes Journal of Anthropological Archaeology 3, 259-299.

Lyman, R.L., 1985. Bone frequencies: differential transport, in situ destruction, and the MGUI. Journal of Archaeological Science 12, 221-236.

Lyman, R.L., 1994. Vertebrate Taphonomy. Cambridge University Press.

Lyman, R.L., 2003. The influence of time averaging and space averaging on the application of foraging theory in zooarchaeology. Journal of Archaeological Science 30, 595-610.

Lyman, R.L., 2008. Quantitative Paleozoology. Cambridge University Press.

MacArthur, R.H., Pianka, E.R., 1966. On optimal use of a pathcy environment. The American Naturalist 100, 603-609.

Mackie, R.J., Hamlin, K.L., Pac, D.F., 1982. Mule Deer, Odocoileus hemionus. In: Chapman, J.A., Feldhamer, G.A. (Eds.), Wild Mammals of North America: Biology Management and Economics. Johns Hopkins University Press, Baltimore, pp. 862-877.

Mackie, R.J., Kie, J.G., Pac, D.F., Hamlin, K.L., 2003. Mule Deer, Odocoileus hemionus, In: Feldhamer, G.A., Thompson, B.C., Chapman, J.A. (Eds.), Wild Mammals of 
North America: Biology, Management, and Economics, second ed. Johns Hopkins University Press, Baltimore, pp. 889-905.

Madsen, D.B., 1993. Testing diet breadth models: examining adaptive change in the Late Prehistoric Great Basin. Journal of Archaeological Science 20, 321-329.

Magurran, A.E., 1988. Ecological Diversity and its Measurement. Princeton University Press, Princeton.

Magurran, A.E., 2004. Measuring Biological Diversity. Blackwell Publishing, Oxford.

McGuire, K., Hildebrandt, W.R., 1994. The possibilities of women and men: gender and the California milling stone horizon. Journal of California and Great Basin Anthropology 16, 41-59.

McGuire, K., Hildebrandt, W.R., 2005. Re-thinking Great Basin foragers: prestige hunting and costly signaling during the Middle Archaic period. American Antiquity 70, 695-712.

McGuire, K., Hildebrandt, W.R., Carpenter, K.L., 2007. Costly signaling and the ascendance of no-can-do archaeology: a reply to Codding and Jones. American Antiquity 72, 358-365.

Menard, S., 2002. Applied Logistic Regression Analysis, second ed. Sage Publications, Thousand Oaks.

Metcalfe, D., Barlow, K.R., 1992. A model for exploring the optimal trade-off between field processing and transport. American Anthropologist 94, 340-356.

Metcalfe, D., Jones, K.T., 1988. A reconsideration of animal body-part utility indices. American Antiquity 53, 486-504.

Moratto, M.J., 1984. California Archaeology. Academic Press, Orlando.

Mills, W.W., Rondeau, M.F., Jones, T.L., 2005. A fluted point from Nipomo, San Luis Obispo County, California. Journal of California and Great Basin Anthropology $25,68-74$.

O'Connell, J.F., Hawkes, K., 1984. Food choice and foraging sites among the Alyawara. Journal of Anthropological Research 40, 504-535.

O'Connell, J.F., Marshall, B., 1989. Analysis of kangaroo body part transport among the Alyawara of Central Australia. Journal of Archaeological Science 16, 393405.

O’Connell, J.F., Hawkes, K., Blurton Jones, N., 1988. Hadza hunting, butchering, and bone transport and their archaeological implications. Journal of Anthropological Research 44, 113-161.

Orians, G.H., Pearson, N.E., 1979. On the theory of central place foraging. In: Horn, D.J., Stairs, G.R., Mitchell, R.D. (Eds.), Analysis of Ecological Systems. State University Press, Columbus, pp. 155-177.

Orton, C., 2005. Sampling in Archaeology. Cambridge University Press, Cambridge.

Pilling, A.R., 1951. The surface archaeology of the Pecho Coast, San Luis Obispo County, California. The Masterkey 25, 196-200.

Pilloud, M.A., 2006. The impact of the medieval climatic anomaly in prehistoric California: a case study from Canyon Oaks, CA-ALA-613/H. Journal of California and Great Basin Anthropology 26, 179-191.

Plourde, A.M., 2008. The origins of prestige goods as honest signals of skill and knowledge. Human Nature 19, 374-388.

Potter, J.M., 1997. Communal ritual and faunal remains: an example from the dolores Anasazi. Journal of Field Archaeology 24, 353-364.

Potter, J.M., 2000. Pots, parties and politics: communal feasting in the American Southwest. American Antiquity 65, 471-492.

R Development Core Team, 2009. R: A Language and Environment for Statistical Computing. R Foundation for Statistical Computing, Vienna, Austria

Raab, M.L., Larson, D.O., 1997. Medieval climatic anomaly and punctuated cultura evolution in coastal southern California. American Antiquity 62, 319-336.

Reitz, E.J., Wing, E.S., 2008. Zooarchaeology, second ed. Cambridge University Press, Cambridge.

Rogers, D.B., 1929. Prehistoric Man of the Santa Barbara Coast, California. Santa Barbara Museum of Natural History, Special Publications No. 1.

SAS Institute Inc., 2007. JMP, Version 7. SAS Institute Inc., Cary, NC, 1989-2007.

Schoener, T.W., 1971. Theory of feeding strategies. Annual Review of Ecology and Systematics 2, 369-404.

Shennan, S., 2008. Evolution in archaeology. Annual Review of Anthropology 37. 75-91.

Sih, A., Christensen, B., 2001. Optimal diet theory: when does it work, and when does it fail? Animal Behaviour 61, 379-390.

Simms, S., 1985. Acquisition costs and nutritional data on great basin resources. Journal of California and Great Basin Anthropology 7, 117-125.

Smith, E.A., 1991. Inujjuamiut Foraging Strategies: Evolutionary Ecology of an Arctic Hunting Economy. Aldine de Gruyter, New York.

Smith, E.A., 2004. Why do good hunters have higher reproductive success? Human Nature 15, 343-364.
Smith, E.A., Bliege Bird, R., Bird, D.W., 2000. Turtle hunting and tombstone opening: public generosity as costly signaling. Evolution and Human Behavior 21, 245261.

Smith, E.A., Winterhalder, B., 1992. Natural selection and decision-making: some fundamental principles. In: Smith, E.A., Winterhalder, B. (Eds.) Evolutionary Ecology and Human Behavior. Aldine de Gruyter, New York, pp. 25-60.

Stevens, N.E., Codding, B.F., 2009. Inferring the function of flaked stone projectile points on California's Central Coast. California Archaeology 1, 7-27.

Stevens, N.E., Fitzgerald, R.T., Farrell, N., Giambastiani, M.A., Farquhar, J.M., Tinsley, D., 2004. Archaeological Test Excavations at Santa Ysabel Ranch, Paso Robles, San Luis Obispo County, California. MS on file at the California Historic Resources Information System, Central Coast Information Center, University of California, Santa Barbara.

Stevens, D.W., Krebs, J.R., 1986. Foraging Theory. Princeton University Press.

Stine, S., 1994. Extreme and persistent drought in California and Patagonia during medieval time. Nature 369, 546-549.

Stine, S., 2000. On the medieval climatic anomaly. Current Anthropology 41, 627628.

Stiner, M.C., 2001. Thirty years on the "broad spectrum revolution" and paleolithic demography. Proceedings of the National Academy of Sciences 98, 6993-6996.

Stiner, M.C., 2006. Middle paleolithic subsistence ecology in the mediterranean region. In: Hovers, E., Kuhn, S.L. (Eds.), Transitions Before the Transition: Evolution and Stability in the Middle Paleolithic and Middle Stone Age. Springer, New York, pp. 213-231.

Stiner, M.C., Munro, N.D., 2002. Approaches to prehistoric diet breadth, demography, and prey ranking systems in time and space. Journal of Archaeological Method and Theory 9, 181-213.

Stiner, M.C., Munro, N.D., Survoell, T.A., 2000. The tortoise and the hare: small-game use, the broad-spectrum revolution, and paleolithic demography. Current Anthropology 41, 39-73.

Stiner, M.C., Beaver, J.E., Munro, N.D., Surovell, T.A., 2008. Modeling paleolithic predator-prey dynamics and the effects of hunting pressure on prey 'choice'. In: Bocquet-Appel, J.P. (Ed.), Recent Advances in Palaeodemography. Springer, New York, pp. $143-178$

Stuiver, M., Reimer, P.J., Reimer, R.W., 2005. CALIB 5.0., Electronic document, <http://calib.qub.ac.uk/calib/> (accessed December, 2008).

Stuiver, M., Reimer, P.J., 1993. Extended 14C database and revised CALIB radiocarbon calibration program. Radiocarbon 35, 215-230.

Stutz, A.J., Munro, N.D., Bar-Oz, G., 2009. Increasing the resolution of the broad spectrum revolution in the Southern Levantine Epipaleolithic (19-12 ka). Journal of Human Evolution 57, 294-306.

Ugan, A., 2005. Does size matter? Body size, mass collecting, and their implications for understanding prehistoric foraging behavior. American Antiquity 70, 75-89.

Wiess, E., 2002. Drought-related changes in two hunter-gatherer California populations. Quaternary Research 58, 393-396.

Whitaker, A., 2008. The Role of Human Predation in the Structuring of Prey Populations in Prehistoric Northwestern California. Unpublished PhD Dissertation, University of California, Davis.

Whitaker, A., 2009. Are deer really susceptible to resource depression? Modeling Deer (Odocoileus hemionus) populations under human predation. California Archaeology 1, 93-108.

Wilson, D.S., 1976. Deducing the energy available in the environment: an application of optimal foraging theory. Biotropica 8, 86-103.

Winterhalder, B., 1981. Foraging strategies in the boreal forest: an analysis of cree hunting and gathering. In: Winterhalder, B., Smith, E.A. (Eds.), Hunter-Gatherer Foraging Strategies: Ethnographic and Archaeological Analyses. University of Chicago Press, pp. 66-98.

Winterhalder, B., Smith, E.A., 2000. Analyzing adaptive strategies: human behavioral ecology at twenty-five. Evolutionary Anthropology 9, 51-72

Winterhalder, B., Bettinger, R.L., 2010. Nutritional and Social Benefits of Foraging in Ancient California. California Archaeology, in press.

Winterhalder, B., Lu, F., 1997. A forager-resource population ecology model and implications for indigenous conservation. Conservation Biology 11, 1354-1364.

Zahavi, Amotz., 1975. Mate selection - A selection for a handicap. Journal of Theoretical Biology 53, 205-214.

Zeanah, D.W., 2004. Sexual division of labor and central place foraging: a model for the Carson Desert of Western Nevada. Journal of Anthropological Archaeology $23,1-32$. 